\title{
ASGARİ ADALET KAVRAMLAŞTIRMASI ÜZERİNE: ADALETİN ASGARİ İLKELERİ
}

ON THE MINIMUM CONCEPTION OF JUSTICE: THE MINIMUM PRINCIPLES OF JUSTICE

\author{
Sururi AKTAŞ* ${ }^{*}$ (iD)
}

\begin{tabular}{l} 
Makale Bilgi \\
\hline Gönderi: 18/01/2021 \\
Kabul : 18/03/2021 \\
Anahtar Kelimeler \\
\hline Adalet Kavraml, \\
Adaletin Ilkeleri, \\
Asgari Adalet \\
Kavrami, \\
Adaletin Asgari \\
Ilkeleri..
\end{tabular}

\begin{abstract}
Özet
https://dai.org//10.21492/inuhfd.863401 doi

Bu makale çalışmasında, Hans Kelsen gibi hukuki pozitivistler tarafından sübjektif ahlaki bir değer yargısı olması ve belirsizlikler taşıması gerekçesiyle hukuk kavramının dışında tutulmak istenilen adalet değerinin, kolayca reddedilemeyen oldukça yüksek bir belirlilik alanına sahip olduğu ortaya konmaya çalışılmıştır. Asgari adalet ilkelerinin oluşturduğu bu belirlilik alanı "asgari adalet kavramı" olarak tanımlanmıştır. Asgari adalet kavramlaştırmasının olanaklığı, yöntem olarak 1lımlı hukuki pozitivizmi savunan H.L.A Hart'ın hukuk kuralının belirlilik ve belirsizliğine ilişkin yaptığı analiz, yine Hart'ın "doğal hukukun asgari içeriği” tanımlaması, doğal hukukçu Lon L. Fuller'ın ahlakla ilgili yaptığı analiz ve David Schmidtz'in periyodik cetvel benzetmesiyle desteklenmiştir. Bir asgari adalet kavramının inşa edilmesi ve bu yönde bir hassasiyet meydana getirilmesinin, pozitif hukuka bir değer ölçüsü oluşturması bakımından önemli olduğunun altı çizilmiştir. Çalışmada "asgari adalet kavramı”nı oluşturduğu düşünülen bazı ilkeler genel hatlarıyla açıklanmaya çalışılmıştır. Ayrıca asgari adalet kavramı içinde yer verilen adalet ilkelerinin sayı bakımından mutlak olmadığı, yenilerinin eklenebileceği ve dolayısıyla ucu açık bir öneri niteliğinde olduğu vurgulanmıştır. Sonuç bölümünde asgari adalet kavramını oluşturan adalet ilkelerinin nitelikleri ve pozitif hukuk bakımından taşıdığ önem ortaya konmaya çalışılmıştır.
\end{abstract}

\section{Article Info}

Received: 18/01/2021

Accepted: 18/03/2021

\section{Keywords}

The Concept of Justice, The Principles of Justice, The Minimum Concept of Justice,

The Minimum Principles of Justice.

\begin{abstract}
In this article it is tried to reveal that the value of justice, which is wanted to be excluded from the concept of law by some legal positivist like Hans Kelsen because of that it is a subjective moral judgement and has uncertainties, has area of high certainty which can not be easily rejected. This certain area which is formed of minimum principles of justice was defined as "the minimum concept of justice". The possibility of minimum conception of justice was supported, as methods, by soft positivist H. L. A Hart's analysis about determinacy and indeterminacy of a legal rule and his conception of "minimum contend of natural law", by Lon L. Fuller's analysis about morality and by the analogy of periodic table that David Schmidtz used for the elements of justice. In order to form a value measure for positive law it is underlined that it is important to build a minimum concept of justice and to create sensitivity about it. In the article, some principles that are thought to constitute "the minimum concept of justice" are tried to be explained only in their general lines. Additionally, it was emphasized that the principles of justice constituted for the minimum concept of justice are not absolute in terms of number; new principles can be included and therefore they are a matter of choice about an open-ended suggestion. In the part of conclusion the nature of the principles of justice that constitute "the minimum concept of justice" and their importance for positive law are tried to set forth.
\end{abstract}

"Prof. Dr., Erzincan Binali Yıldirım Üniversitesi, Hukuk Fakültesi, Hukuk Felsefesi ve Sosyolojisi Anabilim Dalı. 


\section{GİRIŞ}

Adalet değeri eski çağlardan beri felsefenin ve hukuk biliminin konusu olagelmiştir. Herkes adaletsizlikten yakınır; ancak adaletin ne olduğu konusundaki ihtilaflar bir türlü aşılamaz. Belki adalet değerinin bu kavramsal yatışmazlığı, bizzat adaletin kendi doğasının bir gereği olabilir. Kelsen gibi hukuki pozitivistler açısından sübjektiflik, değişkenlik ve belirsizlik, bilimin niteliğine yakışmadığı için adalet gibi ahlaki değerler, hukuk kavramının ve biliminin kapsamına dahil edilmez ${ }^{1}$. Özellikle Kelsen, adaletin, sübjektif bir değer yargısı olarak bireylerin mutluluk özlemi olduğunu, toplumdaki bireylerin mutluluğunu sağlamak için ise hangi ihtiyaçlarının karşılanması gerektiğinin rasyonel olarak yanıtlanamayacağını ileri sürerek kavramın göreceliliğine işaret eder ${ }^{2}$. Ancak Kelsen, yine de adalet kavramına objektif bir anlam kazandırılacaksa, bunun, pozitif hukuk kurallarının uygulanması gereken bütün olaylara aynı şekilde uygulanması anlamında yasallıktan (legality) başka bir şey olamayacağın ${ }^{3}$; bir davranışın adilliğinin, yasallığı ile aynı olduğunu söyleyerek adaleti, pozitif hukuk düzeniyle özdeşleştirir ${ }^{4}$. Dolayısıyla Kelsen açısından pozitif hukuk dışında adalet, göreceli yargıları ifade eder ${ }^{5}$.

Ahlaki göreceliliğin (rölativizmin) ürettiği tartışmalar yanında, servet ve gelirlerin bölüşümüne dönük siyaset ve siyaset felsefesinin ortaya çıkardığı tartışmalar, adalet değerinin etrafinda dönen bir ihtilaflar yörüngesi oluşturmuştur.

Liberal ekonominin (kapitalizmin) egemen olmasıyla birlikte adalet değerine ilişkin olarak siyaset ve hukuk felsefesinin ilgisi daha çok dağıtıcı ve sosyal adalete (servet ve gelirin bölüşümüne) yönelmiş̧ir. Bu bağlamda adalet tartışmaları, dağıtıcı ve sosyal adalete taraf olanlar ile olmayanlar arasında geçmektedir. Örneğin Rawls ${ }^{6}$ ve Miller ${ }^{7}$ dağıtımcılığa dayalı bir sosyal adalet kavramını temellendirerek savunmaya çalışırken, Amartya $\operatorname{Sen}^{8}$ de kapasite geliştirilmesine dayalı sosyal adaleti savunmaktadır. Nozick ${ }^{9}$ ve Hayek ${ }^{10}$ gibi liberaller dağıtımcılığı ve dolayısıyla sosyal adaleti eleştirerek reddederler. Akademik olarak hukukun diğer alanlarında adalet değerinin teorik tartışması çok fazla ilgi çekmemektedir. Genelde hukuk disiplinleri, kendi alanlarında yeri geldikçe belirli bağlamlarda adalete vurgu yapmaktadırlar. Bu durum, medeni hukuk (civil law) ve ceza hukuku gibi hukukun en eski alanlarında adalet değerinin, kurumlar ve kurallar bağlamında görece istikrar kazanmasından kaynaklanmaktadır. Ancak yine de bu alanlarda, ülkeler bazında farklılıkların ortadan kalkmadığı bir gerçektir. Özellikle Batı hukuk sistemleri kapsamındaki ülkelerin pozitif hukuk kurum ve kuralları arasında adalete ilişkin farkların oldukça azaldığını söyleyebiliriz. Küreselleşmeyle birlikte, dünya ülkelerinde hukuk sistemleri arasındaki yakınlaşmanın, uygulama bazında olmasa da, yasal ve sistemik düzeyde gittikçe arttığını söyleyebiliriz. Ancak küreselleşme ne yazık ki çoğulcu bir etkileşim anlayışıyla değil de daha çok Batı hukuk sistemlerinin etkisi altında cereyan etmektedir. Özellikle "insanın yaratılmış doğası" tasavvuruna dayanan doğal hukuk anlayışları, daha çok demokratik iradeyle belirlenen hukuk anlayışı lehine azalmaktadır. Bu, klasik doğal hukukun, bir anlamda demokrasiyle belirlenen haklar kavrayışına dönüşmesi anlamına gelmektedir ${ }^{11}$.

Gerek bölüşüm ahlakı ve gerekse diğer alanlarda ne kadar içerik (substantive) açısından güçlü bir adalet anlayışını kavramlaştırmaya çalışırsak, o kadar üzerinde anlaşılması daha zor bir adalet kavramı inşa etmiş oluruz. Başka bir anlatımla idealize edilmiş bir adalet kavramı doğal olarak daha

\footnotetext{
${ }^{1}$ KELSEN, Hans: "The Pure Theory of Law and Analytical Jurisprudence", Harvard Law Review, 55(1), 1941 , s.45 vd; GÖZLER, Kemal: Hukuka Giriş, 15.Baskı, Ekin Yayını, Bursa 2018, s.420; bkz. CULLISON, Allan D., "Morality and the Foundations of Legal Positivism", Valparaiso University Law Review, 20(1),1985, s.62-63; CURZON, L. B: Jurisprudence, 2nd Edition, Cavendish Publishing, London-Sydney 1995, s.83.

${ }^{2}$ KELSEN, Hans: General Theory of Law and State (General Theory), (Translated by Andres Wedberg), Third Printing, Harvard University Press, Cambridge, Massachussets 1949, s.6 vd.

${ }^{3}$ KELSEN, General Theory, s.14.

${ }^{4}$ KELSEN, General Theory, s.14.

${ }^{5}$ KELSEN, General Theory, s.6-14.

${ }^{6}$ RAWLS, John: A Theory of Justice, Revised Edition, Sixth Printing, Harvard University Press, Cambridge, Massachussets 2003, s.228 vd, 242 vd.

${ }^{7}$ MILLER, David: Social Justice, Clarendon Press, Oxford 1976, (Part I).

${ }^{8}$ SEN, Amartya: The Idea of Justice, The Belknap Press of Harvard University Press, Cambridge, Massachussets 2011, s.231 vd.

${ }^{9}$ NOZICK, Robert: Anarchy, State and Utopia, Oxford 1974, s.149-182; bkz. GÜRLER, Sercan: Ahlak ve Adalet: Çağdaş Ahlak Felsefesi ve Adalet Sorunu, 1.Baskı, Legal Yayıncılık, İstanbul 2007, s.97.

${ }^{10}$ HAYEK, Friedrich August von: Kanun, Yasama Faaliyeti ve Özgürlük Cilt.II (Sosyal Adalet Serabı), (Çev. Mustafa Erdoğan), 1.Bask1, Türkiye İş Bankası Kültür Yayınları, 1995 (tümüne).

${ }^{11} \mathrm{Bu}$ değişim doğal hukukun kendi içerisinde bir değişim olarak da okunmaktadır. Söz konusu değişim, "teleolojik doğal hukukun", sübjektif hakkı esas alan "kökensel insan doğasına” dayalı doğal hukuk anlayışına doğru gerçekleştiği analiz edilmektedir. (Bkz. USLU, Cennet: Doğal Hukuk ve Doğal Haklar, Liberte Yayını, Ankara 2009, s.48-149,93 $\mathrm{vd}, 117 \mathrm{vd}$.)
} 
fazla tartışmayı beraberinde getirir. Çünkü değerler, ulaşılması gereken hedefler olarak, siyaset ve hukuk felsefesinin tartışma konusu olmaya devam etmektedir. Ancak, adalet değerinin tartışmalı bir sahayı bünyesinde barındırması, bu değerin hukuk biliminden (jurisprudence) dışlanmasının gerekçesini oluşturamaz. Bütün değerler gibi adalet değerinin de tartışmalı bir niteliğe sahip olması, hukuk alanında nihilist bir ahlak felsefesinin oluşturulmasına bahane olamaz. Değerlere sırtını dönmüş bir hukuk bilimi, pozitif hukuk kurallarının doğruluk ölçütü konusunda sadece güç ve zorlamayı kendisine esas alması kaçınılmaz olacaktır.

Adalet kavramına ilişkin idealize edilmiş teorilerin devam etmesi, adalet kavramının giderek daha zengin bir içerik almasını sağlar. Ancak önemli bazı adalet ilkelerinin yer aldığı asgari bir adalet kavramını oluşturmak, pozitif hukukun sahip olması gereken asgari bazı biçimsel ve maddi özellikler bakımından önem arz etmektedir. Bundan dolayı bazı pozitivistlerin rölativist anlayışlarının aksine, adalet değerine ilişkin herkesin üzerinde öyle veya böyle uzlaşabileceği bir ilkeler demetinin mümkün olabileceğini düşünüyoruz. Bu ilkeleri demetinin oluşturacağı çekirdek alanı, "asgari adalet kavramı" (minimal conception of justice) olarak nitelendiriyoruz. Hukuk devleti idealine yaklaşma, haklar ve yükümlükleri belirleme ve hukuk düzeninin etkililiğini sağlama açısından "asgari adalet kavramı" alanın felsefi ve hukuksal açıdan tartışılmasının önemli olduğu kanaatini taşımaktayız. Bazı ilkelerle içeriğini inşa edeceğimiz asgari adalet kavramı, siyasi görüşlerden etkilenmeyen veya asgari düzeyde etkilenebilen bir çekirdek alan niteliğindedir. Bu sert çekirdek alan, uzun bir zaman dilimi sürecince gelişerek billurlaşmış (kristalleşmiş) ahlaki bir alanı oluşturur.

\section{YÖNTEM}

Adalet değerine asgari bir kavram kazandırılması konusunda, Hart'ın hukuki belirsizlik konusunda yaptığı çözümlemeyi (analizi) bir yöntem olarak esas alabiliriz. Hart, herhangi bir kuralın bir belirsizlik alanı ve bir de belirlilik alanı bulunduğunu söyler. Kuralın belirlilik alanı, kuralın kapsamına tartışmasız olarak giren durumlar ile söz konusu kapsama tartışmasız olarak girmeyen durumlardan oluşur. Hart'ın alışılmış örneği, "parka araçla girmek yasaktır" kuralıdır ${ }^{12}$. Bu kuralın kapsamına kesin olarak giren ve girmeyen olgu ve durumlar vardır. Bunlar kuralın belirli alanıdır. Kamyonet veya otomobil kuralın kapsamına kesin olarak dahil olan bir durumdur; sandviç veya bir demet çiçek de kuralın kapsamına kesin olarak girmeyen durumlardır. Bir de kuralın belirsizlik alanı (penumbra) bulunur. Bebek arabası veya bir kaykayın söz konusu kuralın kapsamına girip girmeyeceği ise tartışmalı bir durum olarak kuralın belirsizlik alanını oluşturur ${ }^{13}$. Asgari adalet kavramını oluştururken Hart'ın bu analizinden faydalanabiliriz. Adalet değerinin, bazı standart ve ilkelerinin olması reddedilemeyecek bir olgudur. Örneğin, "suç ile ceza arasında bir orantının bulunması", "hukuk kurallarının herkese eşit bir biçimde uygulanması" gibi ilkeler herkes tarafından kabul edilen ilkelerdir. Doğal olarak bütün ilkeler gibi, adalet ilkeleri de her zaman soyuttur; adalet kavramı, ilkelerin uygulanacağı koşulları somut olarak belirlemez. Örneğin suç ile ceza arasında nasıl bir orantının olması gerektiğinin mutlak bir standardından kolayca söz edemeyiz. Bir ülkenin suç ve ceza politikası, bu oranın belirlenmesinde etkili olur. Ancak sağduyu ve diğer karşılaştırmalı analizler, suç ile ceza arasındaki orantının aşııı şekilde dengesiz bir boyutta olmasının adil olmayacağını telkin eder.

Hart' $1 n$ "doğal hukukun asgari içeriğ $1{ }^{14 "}$ " tanımlaması da, asgari adalet kavramlaştırmasında bize yöntem olarak ilham verebilir. Hart, hukuki pozitivizmin ayrılabilirlik tezine bağlı olmasına karşın, hukuk ve ahlakın, toplumsal hayatı sürdürmenin asgari gereklerini karşılaması için belirli bir içeriğe sahip olması gerektiğini savunmuştur ${ }^{15}$. Bu bağlamda Hart bir sosyal organizasyonun, "şiddetin sınırlandırılması ${ }^{16 ", ~ " k a r s ̧ ı l ı k l ı ~ k a c ̧ ı n m a ~ v e ~ u z l a s ̧ m a ~}{ }^{17}$ ", "saldırganlık ve bencilliğin sınırlandırılması ${ }^{18 ",}$ "mülkiyet kurumunun asgari bir biçimi ${ }^{19 "}$ " ve "kurallara itaati garanti edecek zora dayalı yaptırım düzeni ${ }^{20 "}$ kurallarını içermesi gerektiğini savunmuştur ${ }^{21}$. Yukarıda görüldügü gibi Hart, doğal hukukun

\footnotetext{
${ }^{12}$ HART, H.L.A.: The Concept of Law, Second Edition, (With a Postscript Ed. by Penelope A. Bulloch and Joseph Raz) Clarendon Press-Oxford 1994, s.126- 128.

${ }^{13}$ HART, s.128-136; ŞAHIN CEYLAN, Şule: H.L.A Hart'ın Hukuk Kavramı, 1.Baskı, XII Levha Yayını, İstanbul 2014 , s. 143 vd.

${ }^{14}$ HART, s. 193 .

${ }^{15}$ HART, s.193; bkz. ŞAHIN CEYLAN, s.202; CURZON, s.93.

${ }^{16}$ HART, s.194.

${ }^{17}$ HART, s. 195 .

${ }^{18}$ HART, s.196; bkz. SSAHIN CEYLAN, s.205.

${ }^{19}$ HART, s.196.

${ }^{20}$ HART, s. 197 vd.

${ }^{21}$ Hart'ın doğal hukukun asgari içeriğine ilişkin kuralları konusunda ayrıca bkz. ŞAHIN CEYLAN, s.204-208; BAYLES, Michael D.: Hart's Legal Philosophy, Kluwer Academic Publishers, Netherlands 1992, s.117-119; DRURY,
} 
asgari içeriğine ilişkin bir kavramlaştırmaya gitmiştir. Böyle bir kavramlaştırmayı adalet ideali açısından da gerekli görüyoruz.

Adaletin asgari ilkelerini kavramlaştırmada bize ilham verecek bir diğer düşünce de Fuller'ın hukukun içsel ahlakına ilișkin tahlilidir. Fuller, hukuka özgü ahlakı, "ödev ahlakı" ve "arzu edilen (ideal) ahlak" şeklinde bir skalaya benzetir ${ }^{22}$. Skalanın belirli bir noktasının altında ödev ahlakı bulunur. Ödev ahlakı yerine getirilmediği zaman bir kınama söz konusudur; ancak ödev ahlakına uymak, bir övgüyü hak etmez. Arzu edilen (ideal) ahlak ise, ödev ahlakının sona erdiği skalanın belirli bir noktasından yukarıya doğru yükselir. Arzu edilen (ideal) ahlaka uymamak bir yazıklanma duygusunu oluştursa da, bir kınamayı gerektirmez ${ }^{23}$. Adalet, bir değer olarak güçlü bir içeriğe sahip olmayı hak eden hukuksal bir erdemdir. Ancak adalet değerinin somutlaştırılan ilkeleri de, Fuller'ın içsel ahlakında olduğu gibi, aşağıdan yukarıya yükselen bir skalaya benzerler. Skalanın belirli bir noktasına kadar pozitif hukuk düzenlerine yansıması zorunlu olan ve asla vazgeçilemez ilkeler bulunur. Bunlar, sadece iyi bir hukuk düzeninin oluşturmasında uyulması gereken ilkeler değil, aynı zamanda bir hukuk düzeninin varlık-yokluk göstergeleri olmalıdır. Pozitif hukuk kurallarının herkese eşit şekilde uygulanması gereğini buyuran anayasal bir ilke bu türdendir. Skalanın belirli bir noktasından sonraki ilkeler iyi bir hukuk düzeninin ilkeleridir. Hukuk düzeninin varllğıını gösteren noktanın üzerine çıkmak arzu edilen bir değer olmalıdır. Ancak, skaladaki bu ayrıma ilişkin yaklaşımımız, ayrılabilirlik tezini asla ima etmemektedir. Çünkü, skalanın asgari bölümüyle hukukun varlığı arasında zorunlu bir ilişkinin olduğunu kabul ediyoruz.

Adalet değerinin asgari ilkelerini bir kavram dahilinde ortaya koyma faaliyeti, analitik felsefenin değil, spekülatif felsefenin akli ve sezgisel yöntemine dayalı teorik bir çabadır. Ancak, ahlak, hukuk ve siyaset felsefesinde spekülatif felsefeye başvurmamız kaçınılmazdır. Aksi takdirde, iyi ve adil siyasi kurumlar ve kurallar arayışımız mümkün olmaz. Ahlak, hukuk ve siyaset alanında bir taraftan analitik bir çaba gerekli olurken, diğer taraftan da ahlaki ve hukuki değerleri ortaya koymak için akıl ve sezgiye dayanan spekülatif fikir egzersizine ihtiyacımız vardır. Önereceğimiz asgari adalet ilkeleri hiçbir şekilde mutlak ve sabit bir kavramlaştırmayı zorunlu kılmayacaktır. Tartışmaya açık sürekli zenginleştirebilec ĕgimiz bir nitelikte olacaktır. Schmidtz, adaletin unsurlarını ortaya koyarken, bu unsurların yer aldığı yapıyı, sürekli yenilerinin eklenmesine müsaade eden periyodik cetvele benzetir ${ }^{24}$. $\mathrm{Bu}$ analoji işimize yarayabilir. Biz de Schmidtz'in bu analojisinden yararlanarak asgari adalet kavramını periyodik cetvele benzetebiliriz. Nasıl yeni elementler cetvele işlendiğinde cetvelin formu değişmiyorsa, asgari adalet kavramını oluşturan ilkelere yenileri eklendiğinde veya bazıları değiştirildiğinde de adalet değeri form olarak değişmeyecektir ${ }^{25}$. Ancak, asgari adalet kavramlaştırmasının görece daha yaygın kabul görebilmesi için, sınırlanmaya tabi tutulması gerekir. Kavram ne kadar çok şişkinleştirilirse, üzerindeki tartışmaların yoğunluğu o derece artar. Bu da adalet değerini sulandırmaya çalışan nihilistlerin veya rölativistlerin işini kolaylaştıracaktır.

\section{BİR ASGARİ ADALET KAVRAMININ ÖNEMI}

Hukuk ve ahlak felsefesinin ilgi odağı olan adalet değeri ile ilgili olarak asgari bir kavram alanı belirlemeye çalışmanın naifliğine rağmen, yine de bilinçli olarak ihlal edemeyeceğimiz; ihlal ettiğimizde de büyük bir kötülük işlediğimiz bilincini oluşturmak ve yaygınlaştırmak için bir asgari adalet kavramı oluşturmanın önemli olduğunu düşünüyoruz.

Her şeyden önce, adalet değeri için kolayca ihlal edilemez bir alan belirlemeye çalışmak hukuk düşüncesinin zenginleştirilmesi bağlamında önemli bir felsefi ve zihinsel çabadır. Analitik olmayan bu tür hukuk hikmetine dönük çalışmaların daha da çoğalması gerekir. Bu tür spekülatif arayışlar sonucu oluşan öğretilerin çokluğu, bunların kendi aralarında rekabet etme şansını doğuracaktır. Bu da hukuk ve felsefe disiplinleri açısından düşünsel bir zenginlik olacaktır.

Ahlaki bir değer olarak adalete asgari bir kavram alanı belirlemeye çalışmak, bazı önemli ve vazgeçilemez ilkelerin billurlaşmasını sağlayacaktır. Bazı ilkelerin billurluğu konusunda oluşan bilinç,

S. B., "H.L.A. Hart's Minimum Content Theory of Natural Law", Political Theory, Sage Publications, 9(4), 1981, s.541-544; CURZON, s.93.

${ }^{22}$ FULLER, Lon L.: The Morality of Law, Revised Edition, Yale University Press, New Haven and London 1969, s.42; Fuller, "genellik, ilan edilme (yayımlanma), geriye yürümezlik, açıklık (belirlilik), çelişmezlik, imkânsızı istememe, süreklilik (istikrar) ve resmî eylemler ile ilan edilen kuralların örtüşmesi” biçimindeki ilkeleri hukukun içsel ahlakı olarak tarif eder. (FULLER, s.46-91; ayrıca bkz. AKTAŞ, Sururi: Prosedürel Doğal Hukuk: Fuller'in Hukuk Kavramı, 1.Bask1, XII Levha Yayın1, İstanbul 2011, s.5 vd).

${ }^{23}$ FULLER, s.42; bkz. SUMMERS, Robert S.: "Professor Fuller on Morality of Law", Journal of Legal Education, $18(1), 1965$, s.5 vd.

${ }^{24}$ SCHMIDTZ, David: Adaletin Unsurları, (Çev. Hayrettin Özler), 1.Baskı, Liberte Yayınları, Ankara 2010, s.49.

${ }^{25}$ SCHMIDTZ, s.49. 
bunların ihlalini zorlaştıracaktır. Hukuk eğitimi olmayan vatandaşlar dahi böyle ilkelerin varlığı konusunda bilinçlenecek ve hukuk uygulamalarını bu ilkeler açısından gayri-resmi olarak denetleyeceklerdir.

Asgari adalet kavramlaştırmasını oluşturacak billur ilkeler, bir taraftan yasa koyuculara, diğer taraftan da uygulayıcılara yol gösterecektir. Yasa koyucular kolay kolay bu kristalleşmiş alanı açıkça ihlal edecek yasa yapma girişiminden kaçınacaklardır. Söz konusu ilkeler anayasa koyucu bakımından temel norm statüsünü haiz olabilir. Kelsen'in temel norm faraziyesini, faraziye olmaktan çıkarıp somuta dönüştürme faaliyetinde, asgari adalet ilkelerinin oluşturacağı kavramsal bütünlük, bir tercih seçeneği olarak üzerinde çalışmayı hak edecek bir konudur. Burada Kelsen'in temel norm anlayışı gibi tek bir temel norm da kabul etmek zorunda değiliz. Bu açıdan asgari adalet ilkeleri, hukuk düzeninin temel normlardan bazılarını oluşturabilir.

Pozitif hukuk kurallarını uygulayanlar bakımından asgari adalet kavramlaştırmasının oynayacağı rol daha önemlidir. Pozitif hukuk kurallarının belirsiz olduğu durumlarda asgari adalet ilkeleri açısından yorumlanması gerekecektir. Dolayısıyla, yasaların belirsiz olduğu durumlarda, asgari adalet ilkeleri böyle yasaların nasıl yorumlanması gerektiği hususunda uygulayıcılara kılavuzluk edecektir. Billurlaşmış adalet ilkeleri doğrultusunda yapılacak hukuki yorumlar, sağduyuyu temsil eden vicdani hisleri tatmin edecektir. En azından hukuki belirsizliğin olduğu davalarda, bu tür ilkelere aykırı yorumların meşruiyeti tartışmalı hale gelecektir. Bu bağlamda billurlarmış asgari adalet ilkeleri normatif bir yorum işlevi görecektir. Bu yaklaşım, Dworkin'in kurallar yanında diğer bir standart türü olarak gördüğü ilkelerin (principles) zor davalarda (hard cases) oynadığ rol $^{26}$ gibi bir işlevi yerine getirecektir. Aynı zamanda Dworkin'in tutarlılık (coherence) tezi gereğince pozitif hukuk kuralları, ilkelerle tutarlı bir yap1 oluşturacak şekilde yorumlanması gerekir ${ }^{27}$. Hatta Dworkin'e göre yarg1 kararlarının, adalet şeması için temel olan prensiplerle uygun olması için bazı hallerde hakim, "geçmiş kararların dar çizgisinden" ayrılabiliri ${ }^{28}$. Hâkimin hukuk yaratması gereken kanun boşluğu (lacuna) durumlarında da söz konusu ilkeler ilham verici olacaktır. Hâkimin yaratma faaliyeti billurlaşmış adalet ilkeleri ışığında daha meşru ve haklılaştırılabilecek bir zemine oturacaktır. Aynı şeyler, takdir yetkisinin kullanılması açısından da söz konusudur.

Dolayısiyla asgari adalet ilkeleri, hukuku yorumlama, hukuk yaratma ve takdir yetkisinin kullanılmasında pozitif hukuk dışında ilham verici bir kavram olarak Weber'in kavramsallaştırdığı maddi rasyonaliteyi de sağlayacaktır ${ }^{29}$. Weber her ne kadar biçimsel rasyonaliteyi yüceltmiş olsa da ${ }^{30}$, yorum, hukuk yaratma ve takdir yetkisi gibi faaliyetler bakımından maddi rasyonaliteye ihtiyacımızın olduğu aşikâr gibi görünmektedir. Maddi rasyonalite, pozitif kurallarının dışında, bunların yorumu veya boşluk durumunda yargısal kararlarımızı dayandıracağımız zaman, bir ölçüde belirlilik sağlayabilen doğal hukuk ve evrensel ahlaki öğretiler gibi inançlar ve düşünceler bütününü az çok öngörebilmeyi ifade eder. Biçimsel öngörülebilirlik gibi bir rasyonaliteyi garanti edemezse de, biçimsel rasyonalitenin yokluğunda kararlarımıza yol gösterebilir. Yorum, hukuk yaratma ve takdir yetkisinin en azından hangi maddi ilkelere aykırı olamayacağı hususunda bize kılavuzluk edecek maddi rasyonalitenin gerekliliği aşikârdır. Maddi rasyonalite, aynı zamanda, biçimsel öngörülebilirliğin yanında, yasa koyucuya rehberlik ederek maddi öngörülebilirliği de sağlayacaktır ${ }^{31}$. Yasa koyucunun hangi eylemleri hukuk haline getirebileceğini veya en azından getiremeyeceğini, asgari adalet kavramını oluşturan ilkeler yoluyla kestirebilme imkânımız olacaktır.

\footnotetext{
${ }^{26}$ DWORKIN, Ronald: Hakları Ciddiye Almak, (Çev. Ahmet Ulvi Türkbağ) 1.Bask1, Dost Kitabevi, Ankara 2007, s.114-118,150-154.

${ }^{27}$ Bkz SCHIAVELLO, Aldo: “On 'Coherence' and 'Law': An Analysis of Different Models”, Ratio Juris, 14(2), 2001, s.241; METIN, Sevtap: "Ronald Dworkin'in Hukuk Teorisinde Yorum Yaklaşımı”, İstanbul Üniversitesi Hukuk Fakültesi Mecmuas1, LXI (1-2), 2003, s.53-54,58-59.

${ }^{28}$ DWORKIN, Ronald: Law's Empire (Law's Empire), Harvard University Press, 1986, s.219.

${ }^{29}$ Weber'in maddi ve biçimsel rasyonalite türleri için bkz. DEFLEM, Mathieu: Sociology of Law, (Vision of Scholarly Tradition), Cambridge University Press, 2008, s.45 vd; KALBERG, Stefan: "Max Weber's Types of Rationality: Cornerstones for the Analysis of Rationalization Processes in History" The American Journal of Sociology, 85(5), 1980, s.1155-1159.

${ }^{30}$ Bkz. WEBER, Max: Hukuk Sosyolojisi, (Çev. Latif Boyacı), 1.Bask1, Yarın Yayınları, İstanbul 2019, s.277-284; DEFLEM, s.46.

${ }^{31}$ Bkz. KÖKÜSARI, İsmail: Anayasa Hukukunda Hukuki Güvenlik İlkesi, Birinci Baskı, Adalet Yayınevi, Ankara 2015 , s. $140 \mathrm{vd}$.
} 


\section{OLMASI}

IV. ASGARİ ADALET KAVRAMI ÖNERISINIIN NITELİ̆İ: UCU AÇIK BİR GİRIŞIM

Adalet değerinin ilkeleri, tüketici olarak sayılamaz. Somut durumlarla karşılaştıkça daha genel ilkelerin bu durumlarda daha somut bir hal aldığını görürüz. Somut durumların tüketilemez çokluğu, adalet düşüncesinin (ideasının) belirli ilkeler etrafında sınırlanamazlığına işaret eder. Adalet ilkeleri, genelden özele doğru ilerleyen; özele doğru ilerledikçe daha somut bir hal alan bir karaktere sahiptirler. Genelden özele doğru ilerledikçe, ilkeler, somutlaşmaya paralel olarak tartışmaya daha açık hale gelir. Daha da somutlaşan ilkeler, artık kurallar şekline bürünmeye başlar. Ancak öyle somut durumlar olur ki, bu durumları belirli bir kurala bağlamak, artık akıl yürütmeyle (practical reasoning) mümkün hale gelmez. Trafikte seyrin sağdan mı yoksa soldan mı olması gerektiği meselesi böyledir. Bu noktada hukuk politikasının seçimleriyle karşı karşıya kalırız. Yani, hangi kuralın seçileceği artık bir akıl meselesi değil; bir irade meselesi olur. Ancak bu keyfilik anlamına gelmez. En azından tercih edilecek kuralların, genel ilkelere aykırı olmamasına ilişkin negatif bir testi geçmiş olmaları gerekir. Örneğin gelir vergisinin, $\% 18 \mathrm{mi}$ yoksa $\% 20 \mathrm{mi}$ olacağı siyasi bir tercihtir. Ancak vergilendirmeden hangi grupların muaf tutulacağ 1 eşitlik ve orantılllık meselesini ilgilendirdiği için adaletin temel ilkelerine aykırı olamaz.

Önereceğimiz adalet ilkeleri, doğal olarak mükemmeliyet iddiası taşımayıp, geliştirilebilir ve eleştirel niteliktedir. Dolayısıyla aşağıda sunacağımız ilkeler demeti, sınırlandırıcı (tahdidi) değil, örneklendirici ve ucu açık bir öneri demetini oluşturur. Önerilen söz konusu ilkeler tartışılabilir, artırılıp eksiltilebilirler.

Asgari adalet ilkelerini hukukun evrensel ilkeleri veya doğal hukukun asgari ilkeleri olarak da takdim edebiliriz. Adalet düşüncesine somut içerik kazandırmaya dönük formülasyonlar, tamamen olmasa da büyük ölçüde doğal hukuku somutlaştıran kurallarla örtüşür.

Önereceğimiz asgari adalet ilkelerinin her biri başka bir makalenin konusunu oluşturabilecek nitelikte oldukları için, burada sadece ilkelerle ilgili önemli noktalar vurgulanmaya çalışılacaktır.

Asgari adalet ilkelerini şekli ve maddi ilkeler şeklinde ikiye ayırarak inceleyebiliriz.

\section{ASGARİ ADALET KAVRAMINI OLUŞTURAN ILLKELER}

\section{A. Şekli (Biçimsel) İlkeler}

\section{Yasa Önünde Eşitlik (Aritmetik Eşitlik)}

Eşitlik, en önemli adalet ve hukuk ilkesi olmasına karşın tartışmalardan bağışık değildir. İnsanların hangi açılardan eşit olması veya hangi eşitsizliklerin giderilmesi gerektiği, siyaset ve hukuk felsefesinin sönmeyen tartı̧̧ma alanlarında biridir. İnsanlar "ekonomik açıdan da eşit olmalılar mı veya doğal yeteneklerimiz konusundaki eşitsizlik giderilmeli mi ya da bu doğal eşitsizlikler ne ölçüde giderilmelidir" biçimindeki soruların cevaplarında anlaşma sağlanamamıştır. Bu sorulara vereceğimiz cevaplar, büyük ölçüde benimsediğimiz siyaset felsefesine göre değişiklik arz eder. Ancak eşitliğin çok fazla tartışılmayan asgari bir standardı vardır. Bu da, "yasa önünde eşitlik" ilkesidir. Bu eşitlik açısından insan olan herkesin, rengine, cinsiyetine, kökenine, benimsediği düşünce ve kanaatlerine bakılmaksızın eşit kabul edilmesidir. Başka bir anlatımla yasa önünde eşitlik, insanın cinsiyet gibi doğal özelliklerine bakılmaksızın veya sonradan edindiği bir takım düşünce veya kanaatleri dikkate alınmaksızın hukuk önünde hak özneleri olarak telakki edilmeleridir. Bu anlamdaki eşitlikten sapma, ancak pozitif ayrımcılık yönünde olursa haklılaştırılmaktadır. Örneğin engellilerin durumunun iyileştirilmesi için pozitif ayrımcılık uygulamalarının anayasal veya yasal teminat altına alınması, yasa önünde eşitlik ilkesiyle bağdaştırılmaktadır. Anayasanın 10. maddesi bu bağlamda hem yasa önünde eşitlik hem de pozitif ayrımcılığı aynı maddede telif etmiştir. Yasa önünde eşitlik anlayışı, aritmetik eşitlik ilkesine dayandığı için yasaların içeriğinin, kişilerin diğer özelliklerine bakılmaksızın herkese insan olması dolayısıyla eşit muamele edilmesi gerektiği düşüncesine dayanır.

Bazıları için yasa önünde eşitlik yeterli iken; bazıları için yeterli değildir. Sosyal adalet için, eşitsizlikler arasındaki uçurumların azaltılması gerekir. Bazıları için ise, doğal eşitsizliklerin yarattığı sonuç durumların da bir ölçüde düzeltilmesi gerekir. Bu tartışmalar sonu gelmez bir fikir mücadelesi silsilesini doğurur. Dolayısıyla yasa önünde eşitlik ilkesi daha tartışmasız bir düşünceyi temsil etmektedir. Yasa önünde eşitlik ilkesi, asgari bir ahlaki gerekliliği ifade ettiği için küçümsenmemelidir. Bu ilkeyi uygulamayan veya yeterince önemsemeyen birçok "çağdaş ${ }^{32}$ " ülke söz konusudur.

Diğer yandan yasa önünde eşitliği yasal bazda kabul etmek başka bir şey, tatbikata yansıtmak başka bir şeydir. Dolayısıyla hukuk kuralları bazında bu ilkeyi kabul etmek yetmez. Karar vericilerin

${ }^{32}$ Buradaki "çağdaş" betimlemesi, "hali hazırda veya şimdiki zamanda bulunan” anlamında kullanılmıştır. 
bu ilkeyi samimi bir şekilde uygulamaları gerekir. Ayrıca, diğer adalet ilkeleri için söz konusu olduğu gibi bu ilkenin de uygulamasını güvence altına alabilecek yargısal kurumlara ihtiyaç bulunmaktadır.

Bazılarımız açısından bu tür bir eşitlik anlayışı tatminkâr bulunmayabilir. Ancak en azından adalet değerinin asgari içeriğinin bir unsuru olarak rölativizme karşı belirliliğe hizmet edecektir. Bu ilkeyi hakkıyla uygulayan siyasal rejimler bile bu nedenden dolayı övülmeyi hak ettikleri kabul edilen bir durumdur.

\section{Hukuk Kurallarının Herkese Eşit Uygulanması}

Herkesin üzerinde kolayca ittifak edeceği biçimsel adalet ilkelerinden birisi, yasaların herkese eşit olarak uygulanması zorunluluğudur. Bu zorunluluk, benzer ihtilaflara kuralların aynı şekilde uygulanmasını ifade eder ${ }^{33}$. Kelsen, genelde adalet idesini göreceli olduğu gerekçesiyle hukuk kavramının dışında tutmasına karşın, yasaların benzer olaylara aynı şekilde uygulanmasının bir adalet ilkesi olarak pozitif hukuk düzeniyle uyuşabileceğini söyler ${ }^{34}$. Aslında bu ilke yasa önünde eşitlik kuralının bir uzantısıdır. Yasa önünde eşitliğin hukuki ihtilaflar konusundaki işlevi, benzer ihtilafların görece bir zaman diliminde aynı şekilde çözüme kavuşturulması gereğine hizmet eder. Yasaların herkese eşit uygulanması zorunluluğu, hukukun bütünsel bir niteliğe sahip olmasının bir gereğidir. Dworkin'de bütünlük, hukuk kurallarının önceki kararlarla ahenkli olmasını ifade eder ${ }^{35}$. Kuralların benzer vakıalara uygulanması belirli bir istikrar çizgisini gerektirir. ${ }^{36}$. Elbette kuralların ilânihaye aynı şekilde uygulanmasını mutlak anlamda savunamayız. Değişen sosyo-ekonomik ve teknik koşullar, kuralların yorumunda tedrici ve yumuşak bir değişikliği gerektirebilir. Ancak keyfi olarak ve istikrarı bozacak şekilde benzer davalara farklı hukuki yorumlar uygulanıyorsa, bu durum adaletin asgari gereğinin açık bir ihlali olmaktan başka bir şey değildir.

\section{Ahde Vefa İlkesi: Sözleşmelere Bağlllı̆̆ın Garanti Edilmesi}

Kişilerin verdikleri sözleri yerine getirme yükümlülükleri temel ahlaki bir görevdir. Kuran-1

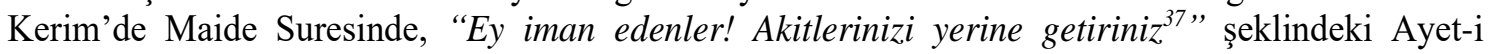
Kerime, sözleşmelere uyulmasını emretmektedir. Yine Bakara Suresi 177. ayet ise, “.......Asıl iyilik..........antlaşma yaptıklarında sözlerini yerine getirenlerin ............... tutum ve davranışlarıdır ${ }^{38,}$, şeklindeki bir hükümle, verilen sözlerin yerine getirilmesi bir "iyilik" ve dolayısıyla ahlaki bir değer olarak emredilmiştir. Adil bir hukuk sistemi bir yana, bir hukuk sisteminin varlığından bahsedebilmemiz için diğer gereklilikler yanında bu hukuk sisteminde serbestçe akt edilen sözleşmelerin yerine getirilmesinin devletçe etkili bir şekilde sağlanması temel bir zorunluluktur. Sözleşmelerin uygulanmasını garanti edemeyen bir siyasi rejimi, adil bir hukuk sistemi ve hatta bir hukuk sistemi olarak kabul etmek söz konusu olamaz. Hart, "doğal hukukun asgari içeriği" tanımlamasında ${ }^{39}$, bir sosyal organizasyonun yaşayabilmesinin ${ }^{40}$ şartlarından biri olarak kişilere, mülkiyet haklarına ve sözleşmelere (promises) saygı duyulmasını gerektiren kurallara itaati garanti edecek bir yaptırım düzeninin varlığını doğal hukukun asgari bileşeni olarak açıklamıştır ${ }^{41}$. İnsanların çoğu kısa vadeli yararlarını bir tarafa bırakarak bu kurallara itaat edebilir ${ }^{42}$. Ancak Hart'ın dediği gibi, insanların "sınırlı anlayış ve irade gücüne" sahip olmalarından dolayı bazı insanlar bu kurallara uymayabilir ve bundan dolayı bu tür kuralların uygulanmasını sağlayacak zorlayıcı bir sisteme ihtiyaç vardir ${ }^{43}$.

\footnotetext{
${ }^{33}$ Bkz. UYGUR, Gülriz: “Adalet ve Hukuk Devleti”, Ankara Üniversitesi Hukuk Fakültesi Dergisi, 53(3), 2004 , s.31.

${ }^{34}$ KELSEN, General Theory, s.14.

35 DWORKIN, Law's Empire, s.176-177,225 vd; TURHAN, Mehmet: “Anayasanın Yorumlanmasında Felsefi Yaklaşım: Ronald Dworkin'e Göre Anayasanın Ahlaksal Okunuşu”, in Ökçesiz, Hayrettin/Uygur, Gülriz/Üye, Saim (ed), Hukuk Felsefesi ve Sosyolojisi Arkivi (HFSA) 26.Kitap, İstanbul Barosu Yayınları, İstanbul 2014, s.452; METİN, s.58-59.

${ }^{36}$ Bkz. GÖZLER, s.314-315.

${ }^{37}$ Kur'an-1 Kerim, Maide Suresi, 5/1, Diyanet İşleri Başkanlığ Meali, https://kuran.diyanet.gov.tr/mushaf/kuran-tefsir1/maide-suresi-5/ayet-1/diyanet-isleri-baskanligi-meali-1 (ErişimTarihi:08.03.2020).

${ }^{38}$ Kur'an-1 Kerim, Bakara Suresi, 2/177, Diyanet İşleri Başkanlığı Meali, https://kuran.diyanet.gov.tr/mushaf/kurantefsir-1/bakara-suresi-2/ayet-177/diyanet-isleri-baskanligi-meali-1 (ErişimTarihi:08.03.2020).

${ }^{39}$ HART, s. 193.

${ }^{40}$ HART, s. 193.

${ }^{41}$ HART, s. $197 \mathrm{vd}$.

${ }^{42}$ HART, s.197; bkz. ŞAHIN CEYLAN, s.206.

${ }^{43}$ HART, s. 197; bkz. ŞAHİN CEYLAN, s.206-208.
} 
Ahde vefa ilkesi, ahlaki bir değer olarak ${ }^{44}$ insanların hem hukuk alanında ve hem de hukuk dışında eylemlerine yol gösteren bir niteliğe sahiptir ${ }^{45}$. Hukukun genel ilkelerinden de sayılan bu ilke ${ }^{46}$ adalet değerinin en önemli bileşenidir. Bundan dolayı asgari adalet gereği, sözleşmelere itaatin sağlanması hem ahlaki ve hem de hukuki bir zorunluluktur. Çünkü kişiler sözleşme yaparak karşı tarafin mal varlığını ve bazı kişisel durumlarını etkileme imkânına sahiptir. Sözleşmeye güvenen tarafın kendi edimini yerine getirmesi dolayısıyla katlandığı külfetlerin karşılığını alması gerekir. Sözleşmeye uymayan taraf, diğer tarafın bu vesileyle uğradığı maddi veya manevi zararı karşılaması ahlakın ve dolayısıyla düzeltici/denkleştirici adaletin bir gereğidir.

\section{Sorumluluğun İrade Özgürlüğüne Bağlanması}

Sorumluluğumuzun bir kısmı kendi karar ve eylem alanlarımızla ilgilidir. Ancak bir kısmı kendi seçimlerimiz olmadan bir otorite tarafından bize yüklenen sorumluluklardır. Vergi ve nafaka gibi kamusal sorumluluklar bu türdendir. Bazı sorumluluklarımız da sözleşme ve haksız fiil gibi doğrudan kendi tercihlerimiz veya eylemlerimizle alakalıdır. Kendi tercih ve eylem alanlarımızla ilgili ahlaki ve hukuki sorumluluğumuz, özgürce karar alabilme yeteneğimize bağlıdır. Eylemlerimiz, kendi özgür karar alabilme yeteneğimizle ilişkilendirilemiyorsa, yani irademiz özgür değilse kararlarımız ve bir şekilde dışa yansımış eylemlerimizden sorumlu olmamalıyız ${ }^{47}$. Özgür iradeyi dışlamaya çalışan radikal determinist görüşler elbette tartışlabilir. Bu bağlamda mutlak anlamda irade özgürlügüünden söz edilemez. Ancak, ortalama sağlıklı bir kişiden iradeyi etkileyen bazı belirleyicileri (determinantları) bertaraf etmesi beklenir. İnsanda bu yetenek, potansiyel olarak vardır. Kaldı ki "bağdaşabilirlik (compatibilism) tezini" savunan birçok yazar, determinizm ile sorumluluğun bir arada bulunabileceğini savunmuştur ${ }^{48}$. Dinler ve kadim gelenekler de sorumluluğu irade özgürlüğüne bağlarlar.

Ancak insan kendi iradesi dışında, özgür karar verebilme yeteneğini geçici veya sürekli olarak kaybedebilir; yaptığı eylemler kendi özgür iradesi dışında gerçekleşebilir. Böyle durumlarda sorumluluktan söz edilemez. Bir hukuk düzeni, bireylerin kendi karar ve eylem alanlarıyla ilgili olarak sorumluluğu, irade özgürlüğüne dayandırılmalıdır. Karar ve eylemlerdeki sorumluluğu, irade özgürlüğüne dayandırmayan bir siyasi rejimin, asgari adalet ölçütünü yerine getirmediği için, meşruluk iddiası zayıflayacaktır.

\section{B. Maddi İlkeler}

\section{Herkese Hakkının Verilmesi}

Herkese hakkının verilmesi veya herkesin kendisine ait olanı alması (suum ius cuique tribuere) vecize haline dönüşmüş bir adalet tanımıdır ${ }^{49}$. Tanım adalet arayışları için cazip olmasına karşın, "kim neyi hak etti" veya "neye göre veya hangi ölçüte göre hak etti" biçimindeki sorular karşısında oldukça içi boş kalmaktadır. Ancak yine de, bu formülün, eylemlerimize yol göstermesi bakımından herkesin öyle veya böyle kabul edebileceği bir somutlaştırması yapılabilir. Kim neye göre hak etti sorusunu, "önceden kabul edilip ilan edilen" pozitif hukuk kurallarına göre elde edilen kazanımlar cevaplayabilir. Ancak biraz daha idealistçe düşünerek, "evrensel olarak yaygın kabul görmüş" kurallara göre elde edilmiş kazanımlar, "herkesin hakkı" formülünü somutlaştıracağını söyleyebiliriz. Örneğin, iradeyi sakatlayan durumlar hariç sözleşme özgürlüğü çerçevesinde rızaya dayalı yapılan ticaretten elde edilenler, "herkesin hakkı" formülü için göz önünde bulundurulması gereken bir ölçüt olabilir.

Kanaatimizce "herkesin hakkı" tanımlaması için sadece belirli kurallar altında çaba sarf edilerek elde edilen haklar değil, aynı zamanda insanın bizzat insan olması hasebiyle doğuştan sahip olması zorunlu olan haklar da gereklidir. Doğal haklar öğretisini savunan bir doğal hukuk teorisyeni için, insanın bizzat insan olması hasebiyle doğuştan sahip olması zorunlu olan haklar perspektifi, "herkesin hakkı" formülü için elzem bir değerlendirme noktasıdır. En azından uluslararası belge ve sözleşmelere geçmiş ve yaygın olarak kabul edilen negatif ve siyasi haklar "herkesin hakkı" formülünü doldurmalıdır.

${ }^{44}$ GÖZLER, s.61.

45 GÖZLER, s.61-62; Bkz. WELLMAN, Carl: The Moral Dimension of Human Rights, Oxford University Press 2011, s.199.

${ }^{46}$ HALL, Stephen: "The Persistent Spectre: Natural Law, International Order and the Limits of Legal Positivism", European Journal of International Law, (EJIL), 2(2), 2001, s.285.

${ }^{47}$ FLETCHER, George P.: "Punishment and Responsibility", in Patterson, Dennis, (Ed.), A Companion to Philosophy of Law and Legal Theory, Second Edition, Wiley-Blacwell, 2010, s.510-511.

48 Klasik ve çağdaş bağdaşabilirlik tezleri için bkz. MCKENNA, Michael: "Compatibilism”, https://plato.stanford.edu/entries/compatibilism/ (ErişimTarihi:05.02.2020).

${ }^{49}$ PLATO: The Republic, (Ed. by G. R. F. Ferrari; Translated: Tom Griffith), Sixth Printing, Cambridge University Press, Cambridge 2003, s.128; DENIER, Yevonne: Efficiency, Justice and Care, Springer, Dordrecht, The Netherlands 2007, s.16; WOLTERSTORFF, Nicholas: Justice: Rights and Wrongs, Princeton University Press 2008, s.22. 


\section{Kamusal Görevlere Geliş Prosedürlerinin Liyakate Göre Belirlenmesi}

Liyakat ahlak alanında eylemlerimize yol gösteren ölçütlerden biridir. Adalet değerinin gerçekleştirilmesi bağlamında liyakat (merit), mutlak değil, sınırlı bir kullanıma sahip olmalıdır. Serbest piyasayı esas alan liberaller, ahlaki alan dışında liyakatin, gelirin yeniden bölüştürülmesinin haklılaştırılmasına dayanak olarak kabul edilmesine karşıdırlar ${ }^{50}$. Serbest piyasa ve sözleşme özgürlüğünün uygulanmadığı alanlarda liyakat ölçütü kullanılabilir ${ }^{51}$. Ancak sözleşme özgürlüğü ve serbest piyasa kurallarının işlediği durumlarda gelirin liyakate göre yeniden paylaştırılmasının haklılaştırılması zordur. Örneğin, hazır giyimin yaygınlaşması neticesinde elbise fiyatlarındaki düşüş dolayısıyla insanların terzilere elbise diktirme (istisna akdi ile) taleplerinin son derece azalması, mesleğini layıkıyla yerine getiren terzilerin gelirlerini oldukça azalmakta ve liyakatlerine uygun bir gelir elde edememektedirler. Bu olguya dayanarak terzilerin liyakat ilkesine göre, toplam gelirden pay almaları için gelirin yeniden bölüştürülmesi savunulamaz.

Ancak, liyakat ahlaki bir ilke olarak tamamen vazgeçilemez ${ }^{52}$. Özellikle sözleşme özgürlüğünün ve serbest piyasa koşullarının uygulanmadığı bazı durumlarda, bu ahlaki ilkeye başvurabiliriz. Bunlardan birincisi, kamusal görevlere gelme prosedürlerini belirlemeye dönük hukuk kurallarını yaparken liyakati esas alabiliriz. Ancak yasal prosedürler işletildikten sonra, ortaya çıkan sonuçları liyakat açısından yeniden dizayn edemeyiz. Örneğin matematik öğretmeni istihdam etmenin prosedürlerini yasayla belirlerken, liyakat olarak, eğitim fakültesi veya fen edebiyat fakültesi matematik bölümünü bitirme ve matematik öğretmenliği için yapılan genel sınavlarda belirli bir puan alma ve alınan puana göre sıralama bakımından açılan kadrolara girebilme şartlarını arayabiliriz. Ancak, adaylardan yapılan sınavı geçemediği için öğretmen olarak atanamayan, iyi matematik öğretmeni olmaya layık kişilerin olması ihtimal dâhilindedir. Sınav korkusundan (fobisinden) sınavı geçemeyen ehliyetli olduğu yaygın olarak bilinen, hatta özel dersler vererek meşhur olmuş kişileri yeniden liyakatlerine uygun olarak sınav dişı öğretmen yapabilir miyiz? Elbette ki bu sorunun yanıtı hayırdır. Çünkü bunu ahlaken arzu etsek bile büyük bir toplumda metodolojik olarak uygulanamaz. Sınavı hasbel kader geçememiş binlerce kişinin liyakatlerini yeniden saptamak sonu gelmez bir süreç olacaktır. Eski küçük kabile toplumlarında olsaydık, liyakatli matematik öğretmenlerini sınav yapmadan kusursuz olarak belirleyebilirdik.

Liyakati adaletin bir unsuru olarak kullanacağımız diğer bir durum, hukuki belirsizlik dolayısıyla yargıcın yorum yapması veya takdir yetkisini kullanması ihtimalleridir. Bu ihtimallerde de yargıç liyakati esas alabilir. Ancak burada da yine liyakati gösteren objektif kriterlerin olması gerekir. İdare hukukunda da, karar vermeye yetkili kişinin takdir yetkisine bırakılan durumlarda, liyakat bir ölçüt olarak esas alınabilir.

\section{Mülkiyet Hakkının, Emek, Rıza ve Mirasa Dayandırılması}

Bir siyasi toplumun hukuk sistemi, iktisadi verimlilik ve adalet açısından, emek, rıza (gönüllü mübadele) ve mirasa (tevarüse) dayanan bir mülkiyet tanımlamasına sahip olması gerekir. Nozick, üç adalet ilkesinden ikisini "asli (ilk) iktisap" ve "gönüllü mübadele" olarak görür ${ }^{53}$. Emek, asli iktisabın kaynağı olabileceği gibi daha sonraki iktisapların (hizmet ve istisna akdi gibi) kaynağı da olabilir. Sürdürülebilir bir çevre anlayışı çerçevesinde, doğayı tahrip etmeden, ekolojik denge ve biyolojik çeşitlilikle uyumlu bir şekilde, emeğini doğayla birleştirerek bir değer ortaya çıkarma girişimine özel mülkiyetin kaynağ 1 olarak saygı duyulmalıdır ${ }^{54}$. Ancak hemcinslerinin hayatlarının idamesi ve sürdürülebilir bir çevre anlayışıyla uyumlu olmayan doğal müdahaleler sınırlandırılmalıdır. Dolayısıyla aslen iktisaba iki sınır getirebiliriz. Bunlardan birincisi, Locke'un özel mülkiyete getirdiği, mealen, diğerlerinin hayatlarını kötüleştiren (tehlikeye atan) sahiplenmelerin meşru görülmemesi ${ }^{55}$; ikincisi sürdürülebilir çevre ve doğa kavramıyla uyuşmayan kazanımların yasaklanmasıdır. Örneğin, bir toplumda tek bir su kaynağının bulunması halinde, bunun özel mülkiyete konu olması halinde,

\footnotetext{
${ }^{50}$ Bkz. HAYEK, F. A.: The Constitution of Liberty, Routledge, London, 1990, s.95-102; NOZICK, s.155-160; HENBERG, M.C.: "Nozick and Rawls on Historical Versus End-State Distribution", The Southwestern Journal of Philosophy, 8(2), 1977, s.77-84; REES, J.C.: "Hayek on Liberty", Philosophy, 38(146), 1963 s.359.

${ }^{51}$ Bkz. AKTAS, Sururi: Hayek'in Hukuk ve Adalet Teorisi, 2.Bask1, Liberte Yayını, Ankara 2018, s.256.

${ }^{52}$ SCHMIDTZ, s.170.

${ }^{53}$ NOZICK, s. $150 \mathrm{vd}$.

${ }^{54}$ Özel mülkiyetin kaynăğ için bkz. LOCKE, John: Second Treatise of Government, Enhanced Media, Los Angeles 2016, Chapter V, Section 27, s.20-21.

${ }^{55}$ Locke'un biraz daha orijinal deyimiyle “.....özel mülkiyet sahiplenmelerinin, geride diğerlerinin ortak kullanımı için yeterli ve iyi bir şekilde birşeyler bırakırsa, hak olarak sahip olunabilir”. (LOCKE, Chapter V, Section 27, s.21 ve Chapter V, Section 33, s.23); bkz. NARVESON, Jan: "Property Rights: Original Acquisition and Lockean Provisos", Public Affairs Quarterly, 13(3), 1999, s.207 vd.
} 
diğerlerinin yaşamlarını kötüleştiren (tehlikeye atan) böyle bir sahiplenme haklı görülemez ${ }^{56}$. Yine aynı şekilde toprağın geri dönülmez tahribini gerektiren müdahaleler, özel mülkiyetin kaynağı olarak görülemez. Diğer insanların hayatlarını tehlikeye atmayan ve sürdürülebilir doğa ve çevre anlayışı çerçevesinde emek sarf edilerek elde edilen değerler (örneğin yapı malzemesi olarak kırsaldan taş toplamak gibi) meşru mülkiyet kaynağı olarak hukuki korumaya layıktır.

Mülkiyet hakkının diğer önemli bir kaynağı rızaya veya gönüllülüğe dayalı mübadelelerdir. Rızaya dayalı/gönüllü mübadeleler irade ve sözleşme özgürlüğü çerçevesinde gerçekleştirilir. Bu koşullarında yapılan hukuki işlemler sonucu elde edilen kazanımlar meşrudur. İnsan doğasından kaynaklanan apaçık ilkelerle tutarlı olan evrensel ahlaka ve evrensel hukuka aykırı olmamak koşuluyla sözleşme özgürlüğünün sağlanması ve sözleşme özgürlüğü neticesinde yapılan rızaya dayalı mübadelelerin ortaya çıkardığı mülkiyet kazanımlarının korunması gerekir. Böyle bir koruma gerek ahlaki açıdan gerekse ekonomik verimlilik ve fayda açısından önemlidir. Ahlaki açıdan sözleşme özgürlüğünün ve sonuçlarının korunması, bireyin karar verme özerkliğinin (otonomisinin) bir gereğidir. Faydacıllk açısından ise sözleşme özgürlüğü ve rızaya dayalı mübadeleler, ticaretin gelişmesine ve mallarının dolaşımına imkân sağlayarak insan toplumlarının refahına katkıda bulunur. Adalet açısından, evrensel hukuk ve ahlaka aykırılık söz konusu değilse, sözleşmede hile ve gabin gibi iradeyi sakatlayan durumlar yoksa ve hukuki işlem, iradelerin serbestçe uyumu çerçevesinde gerçekleşmişse böyle bir hukuki işlem veya sözleşmenin hukuk düzeni tarafından korunması ve sonuçlarının adalet açısından meşru görülmesi gerekir.

Mülkiyetin diğer önemli bir meşru kaynağı mirastır. Miras kavramı, aile kurumuyla yakından bağlantılıdır. Aile ve miras kol kola yürüyerek gelişen geleneksel kurumlardır. Malların tevarüs yoluyla intikal etmesi, aile bireyleri arasındaki doğal bağların bir sonucu veya yine vasiyet gibi özgür iradeye dayalı ölüme bağlı tasarrufların gereğidir. Bu açıdan malların belirli aile bireylerine tevarüs yoluyla intikal etmesi insan doğasıyla uyum içerisindedir. İnsanlar sahip oldukları malların, kendisiyle doğal bağları bulunan veya kendisinin istediği kişilere intikal etmesini bekler. Tevarüsün reddedilmesi, aile kurumuyla uyumlu değildir. Ekonomik açıdan daha eşitlikçi (egalitaryan) bir toplum kaygısı dolayısıyla, mirasın yasaklanması, aile kurumunun önemini zayıflatacaktır. Aynı zamanda tevarüs yoluyla malların intikalinin yasaklanması, ekonomik rasyonaliteyi ve dolayısıyla sermaye birikimini yok edecektir. İnsanların çalışma ve üretme girişimlerinin temelinde, gelecek kuşaklara aktarılacak mal biriktirme güdüsü yatar. Bunun yok edilmesi halinde, çalışma ve üretimin rasyonel temelleri çökecektir. Malların tevarüs yoluyla intikaline getirilen vergilerin, diğerlerine göre fazla olması da yukarıdaki olumsuz sonuçları doğuracaktır. İnsanın kendi emeğinin ve çalışmasının ürünlerinin veya daha önce tevarüs ettiği mallarının kendi varislerine intikalinin engellenmesi, bir kimseden malların zorla gasp edilmesiyle aynı anlama geleceğinden, böyle bir durum adalet değerinin ağır ihlalleri arasında sayılmalıdır.

\section{4. Şeylerin Dengede Olmasi: Denklik Düşüncesi}

Aritmetik eşitlik ilkesine dayalı denklik düşüncesi, Kur'an-1 Kerim'de bir adalet düsturu olarak buyrulmaktadır. Mutaffifin Suresindeki bu düstur, edimler arası dengeyi bozacak her türlü müdahaleyi yasaklayarak ölçme ve tartmada eşitliğe dayalı bir muameleyi emretmektedir ${ }^{57}$. Hukuk felsefesinde dengede olma düşüncesi, denkleştirici (düzeltici) adaletin bir gereğidir ${ }^{58}$. Bu adalet düşüncesi, kişilerin yaptığ 1 sözleşmelerdeki edimlerin de denk olmasını gerektirir ${ }^{59}$. Kişiler sözleşme özgürlüğü gereği, gabin durumu hariç, edimlerin birbirine ağırlı̆̆ını serbestçe kararlaştırabilirler. Ancak, aritmetik eşitliğe dayanan "denklik" fikri sözleşme yaparken ahlaken bize kılavuzluk etmelidir. Sözleşmenin içeriğinin adilliği, "denklik" fikrine dayanırken, biçimsel açıdan da sözleşme özgürlüğüne dayanır. Gabin durumunda sözleşme özgürlüğü zedelendiği için, bu durum edimler arasındaki denklik durumunu da etkileyecektir. Böyle durumlarda, ya edimler yeniden (düzeltici adalet gereği) dengeye getirilmeli veya sözleşme iptal edilebilmelidir. Genelde burada iptal edilebilirlik müessesesi işletilmektedir.

Diğer yandan sözleşmedeki bir edimin yerine getirilmemesi de taraflar arasındaki denkliği bozacaktır. Düzeltici adalet, bozulan ilişkinin yeniden dengeye gelmesini gerektirir. Denkleştirici

\footnotetext{
${ }^{56}$ Bkz. NOZICK, s.179.

Bkz. Kur'an-1 Kerim, Mutaffifin Suresi, 83/1-3, Diyanet İşleri Başkanlığı Meali, https://kuran.diyanet.gov.tr/mushaf/kuran-meal-2/mutaffifin-suresi-83/ayet-1/diyanet-isleri-baskanligi-meali-1 (Erişim Tarihi:08.03.2020).

${ }^{58}$ Bkz. ARISTOTELES: Nikomakhos'a Etik, (Çev. Saffet Babür), Hacettepe Üniversitesi Yayınları, Ankara 1988, V. Kitap, s.100-102.

${ }^{59}$ IŞIKTAÇ, Yasemin: Hukuk Felsefesi, 1.Baskı, Filiz Kitabevi, İstanbul 2004, s.80.
} 
adalet yasa önünde (aritmetik) eşitliğin bir gereği olarak, kişilerin özelliklerine bakmadan onların eylemleriyle ilgilenir. Aristoteles, "Nitekim doğru bir kişinin kötü birini ya da kötü birinin doğru birini dolandirması........arasında hiçbir fark yoktur; yasa yalnızca zararın farkına bakar ve onlara eşit muamele eder ${ }^{60}$ " diyerek denkleştirici adaletin, bozulan denge dolayısıyla ortaya çıkan zararın giderilmesini zarar verenin diğer niteliklerine bakmadan talep eder.

Denkleştirici adalet, edimler arasında bir denklik/denge (muvazene) düşüncesini gerektirdiği gibi, zararla tazminat arasında da bir denkliğin olmasını buyurur ${ }^{61}$. Haksız fiil dolayısıyla ortaya çıkan zarar, zarar gören aleyhine mal varlığında bir azalmayı gerektirdiği için, gördüğü zararı dengeleyecek bir tazminat fikrini gerektirir.

\section{5. Şeylerin Orantılı Olması: Geometrik Eşitlik Düşüncesi}

a. Genel Olarak

Şeylerin tam dengede olmasını ifade eden aritmetik eşitlik düşüncesi bütün hukuki ilişkiler bakımından geçerli değildir. Gerek sezgisel olarak gerekse rasyonel olarak bazı durumlarda şeylerin orantılı olması gerektiğini düşünürüz. Orantıl1lık, Aristoteles'te dağıtıcı adaletin bir ilkesidir ${ }^{62}$. Devlet ile kişiler arasındaki vergi yükümlülüğü ilişkisi bu türdendir. Kişilerin gelirleriyle ödeyecekleri vergiler bir oran ilişkisi çerçevesinde haklılaştırılır. Oran ilişkisi, geometrik eşitlik düşüncesinin bir gereğidir ${ }^{63}$. Dolayısıyla şeylerin orantılı olması gereği, geometrik ilişkilere başvurularak rasyonelleştirilebilir. Örneğin bir çemberin merkezinden çizilen iki doğru arasındaki merkez açıyla bu açının karşısındaki yayın uzunluğu arasında bir orantı vardır. Açı büyüdükçe karşısındaki yay da, o oranda büyür. Bu zorunlu rasyonel orantı ilişkisi, ahlak ve hukuk alanına da yansıtılır. Bazı hallerde ahlaken ve hukuken doğru olan davranış biçimi orantılı veya ölçülü olan davranıştır.

Ancak orantı ilişkisi geometride mutlak olmasına karşın, adalet düşüncesinde veya hukuk da böyle değildir. Geometride merkez açıyla, karşısındaki yayın uzunluğu arasındaki oran ilişkisi sabittir; değişmez. Ancak hukukta şeyler arasındaki mutlak bir orantı söz konusu değildir. Örneğin ilk kez vergi yasaları yapmaya çalışan bir yasa koyucu, gelirlerle vergiler arasındaki oranı belirlerken elinde mutlak bir ölçü yoktur. Oysa geometride aksiyomlar gereği sabit oranlar söz konusudur. Hukukta oranları belirleyecek olan yasa koyucudur.

\section{b. Vergilendirmede Oran}

Belirli bir ülke bağlamında vergi oranlarının belirlenmesi kamunun ihtiyaçları ve diğer ekonomik ve sosyal şartlarla ilgilidir. Ancak yasa koyucu vergi oranlarını belirlerken tamamen serbest değildir. Eşyanın tabiatı gereği, kişilerin ekonomik güçlerinin üstünde vergi konulması düşünülemez. Diğer yandan ekonomik etkinliğe ve mülkiyet haklarına zarar veren aşırı vergilendirme de rasyonalite açısından savunulamaz. Eşyanın tabiatı gereği olan sınırlar içerisinde kalmak şartıyla oranların belirlenmesi siyasi bir tercih olacaktır. Gelirlerle vergiler arasında bir oran belirlendikten sonra, herkesten bu orana göre vergi alınması adaletin bir gereği olur.

Vergilendirme faaliyeti, siyasete duyarlı bir niteliğe sahiptir. Ülkelerin benimsediği siyasi rejime göre vergilendirme tercihleri farklılık arz eder. Ülkelerin benimsediği siyasi rejimler, toplumculuğa kaydığ1 oranda vergilendirme de artış gösterir. Liberal bireyci siyasi rejimler, vergilendirmeyi daha sınırlı tutma eğilimindedirler ${ }^{64}$. Liberal felsefe, ekonomik etkinliği teşvik için kamusal giderleri rasyonalize ederek daha düşük vergilerden yanadır. Dayanışmacı siyasi tercihler dışında, ülkelerin diğer kamusal giderleri de vergilendirme oranında etkili olur. Ancak ekonomik etkinlik ve verimliliğe zarar verecek vergi oranlarından kaçınmak için, kamusal giderleri daha rasyonel bir sürece bağlamak doğru siyasi tercih olacaktır. Bu siyasi değişkenler dışında, vergilendirme topluma dengeli ve orantılı bir şekilde yayılması gerekir. Elbette burada sabit bir orandan söz edemeyiz. Ülkelerin sosyal ve ekonomik koşullarının yarattığı istisnai durumlar hariç, vergilendirme oranları dünyada kabul edilebilirlik sınırlarını aşmamalıdır. Orantısızlıklarla beraber aşırı vergilendirme de mülkiyet haklarını ve kişilerin müteşebbislik güdülerini zayıflatacağı için gerek adalet, gerek rasyonalite ve gerekse ekonomik verimlilik/etkililik açısından savunulamaz.

\footnotetext{
${ }^{60}$ ARISTOTELES, s.100.

${ }^{61}$ IŞIKTAÇ, s.80.

${ }^{62}$ ARİSTOTELES, s.98 vd; IŞIKTAÇ, s.80-81; bkz. KELSEN, Hans: What is Justice: Justice Law and Politics in the Mirrors of Science, Collected Essays by Hans Kelsen, University of California Press, New Jersey 2000, s.127.

63 ARISTOTELES, s.98-99; KNOLL, Manuel: "The Meaning of Distributive Justice for Aristotle's Theory of Constitutions", П Н Г Н / F O N S, I, 2016, s.69 vd.

${ }^{64}$ Bkz. NOZICK, s.169-172; GORDON, David: "Justice and Redistributive Taxation: James Buchanan versus Ludwig von Mises”, The Review of Austrian Economics, 8(1), 1994, s.130.
} 
c. Suç ve Ceza Arasındaki Oran

Ünlü ceza hukuku filozofu Beccaria suçlar ile suçların yaptırımları olan cezalar arasında bir oranın bulunması gerektiğini söyler ${ }^{65}$. Suçlarla cezalar arasında bir oranın olması gerektiği düşüncesi Babil gibi eski geleneklere kadar götürülür ${ }^{66}$. Savunulabilir bazı istisnai durumlar hariç, suçlarla cezaların orantılı olması, adaletin bir gereği olarak kabul edilir ${ }^{67}$. Bir ülkede yeni ihdas edilecek bir suçun cezasının belirlenmesinde, suçun ağırlığı ve konusunun önemi yanında genel olarak bu ülkedeki suçlar ve cezalar arasındaki oranların da göz önünde bulundurulması rasyonel yasa koyucudan beklenen bir yasama faaliyetidir. Cezaları belirlemede etkili olan amiller, genel olarak suçun konusunun önemi, suçun konusu üzerindeki tehlikenin boyutu ve ortaya çıkma ihtimali, suçun konusunda ortaya çıkacak veya çıkmış olan zarar ve failin kast ve taksir gibi kusurunun yoğunluğu olarak sayılabilir ${ }^{68}$. Bunlar bir ülkenin suç ve ceza politikasında da etkili olan belirleyici unsurlardır. Dolayısıyla bir hukuk sisteminde bir suçun cezası, o hukuk sistemindeki diğer suçlar ve cezalar arasındaki oranlara yakın olması beklenir. Ancak, bir suçun cezasını belirlerken, suçun ağırlığı ve öneminin gerektirdiği durumlar hariç, o hukuk sistemindeki suçlar ve cezalar arasındaki oranlardan aşırı uzaklaşmak rasyonel olarak beklenemeyeceği gibi adil bir yasama faaliyeti de olmaz. Belirli suçların bir ülkede fazla işlenmesi dolayısıyla, ceza politikası gereği söz konusu suçların cezaları diğerlerine oranla bir miktar fazla olabilir. Böyle istisnai durumlar her ülkenin suç ve ceza politikasına etki ederek, bazı suçların cezalarının diğerlerinden görece daha ağır olmasına sebep olur. Ancak bunun da bir sınırı vardır. Bir suç için, ağırlığı ve konusunun önemi dikkate alınmaksızın diğer suçlarla cezalar arasındaki orana nazaran aşırı ceza belirlemek adil bir ceza sistemi açısından savunulamaz.

Ülkelerin ceza politikaları, hukuk devletiyle yönetilen diğer ülkelerin suç ve cezalar arasında tespit ettikleri oranlara veya evrensel olarak kabul edilebilen suç ve cezalar arasındaki oranlara yakın olmalıdır. Bazı suçlarla mücadele için bu suçların cezalarının belirlenmesinde, evrensel kabul edilebilen oranlardan biraz uzaklaşılabilir. Ancak, evrensel kabul edilebilen oranları aşırı derecede aşan ceza tayin etmek, adalet değeri açısından savunulamaz. Bentham'ın ve Beccaria'nın belirttiği gibi cezaların caydırıcılığı/önleyiciliği bakımından da, cezanın ağırlığından çok, etkili bir şekilde uygulanıp uygulanmadığına yoğunlaşmak daha elverişli olabilirr ${ }^{69}$. Cezaların kesin bir şekilde uygulanacağından ve infaz edileceğinden emin olunması, caydırıcılık/önleyicilik bakımından daha elzemdir. Örneğin, trafikte kırmızı 1şı ihlalinin, "20 TL idari para ceza karşıllı̆ı"”ın her ihlalde kesin uygulanacağ gerçeği, söz konusu fiilin idari cezasının 200 TL olduğu ve ancak sadece tespit edilebilen az sayıdaki ihlalin cezalandırıldığı durumlarından caydırıcılık/önleyicilik bakımından daha etkilidir ${ }^{70}$.

\section{d. Kusur İle Sorumluluk Arasındaki Oran}

Genel olarak hukuk biliminde kusur ile sorumluluk arasındaki oran, olması gereken bir dengedir. Gerek özel hukukta ve gerekse kamu hukukunda kusur ile sorumluluk arasındaki dengesinin orantılı bir şekilde kurgulanması adalet açısından vazgeçilemez bir gerekliliktir.

Özel hukukta kusur ile sorumluluk arasındaki oran, haksız fiil sorumluluğu bakımından önemli bir ölçüdür. Haksız fiillerde kusur genelde kast ve ihmal şeklinde ikiye ayrılarak incelenir ${ }^{71}$. Ayrıca ağır kusur ve hafif kusur şeklinde de kusur derecelendirilir ${ }^{72}$.

Kusur ile sorumluluk arasındaki oran, hakları daha derinden etkilemesi dolayısıyla ceza hukuku bakımından özel bir önem arz etmektedir. Ceza hukukunda sorumluluk esaslarından birisi kusurdur ${ }^{73}$.

\footnotetext{
${ }^{65}$ BECCARIA, Cesare: Suçlar ve Cezalar Hakkında (İtalyanca Aslından Çeviren: Sami Selçuk), 8.Baskı, İmge Yayınevi, Ankara 2019, s.45.

${ }^{66}$ BALMER, Thomas A.: "Some Thoughts on Proportionality", Oregon Law Review, 87(3), 2008, s.784 vd; ayrica bkz. Sami Selçuk'un "Beccaria'nın Suçlar ve Cezalar Hakkında" adlı eserine yazdığı dipnot 3 için BECCARIA, s.49.

${ }^{67}$ HIRSCH, Andrew von: "Proportionality in the Philosophy of Punishment", Crime and Justice, The University of Chicago Press, 16, 1992, s.56 vd; ÇEÇEN, Anıl: Adalet Kavramı, 2.Basım, Gündoğan Yayınları, Ankara 1993, s.37.

${ }^{68}$ Beccaria, suçların cezaları belirlenirken topluma verdikleri zarar ve suçluyu suça iten etkenlerin göz önünde bulundurulması ve oranların da bunlara göre yapılması gerektiğini söyler (s.45). Ancak daha ileri sayfalarda, cezaların belirlenmesinde sadece toplumsal zararın dikkate alınması gerektiğinin daha doğru olduğunu savunur (BECCARIA, s.51 vd).

${ }^{69}$ BENTHAM, Jeremy: The Theory of Legislation, (Ed. C. K. Ogden), Routledge Kegan Paul, London 1931, s.326; BECCARIA, s.129.

${ }^{70}$ Bkz. BECCARIA, s.129; DEFLEM, s.20.

${ }^{71}$ TEKİNAY, S. Sulhi/AKMAN, Sermet/BURCUOĞLU, Haluk/ALTOP, Atilla: Borçlar Hukuku Genel Hükümler, Gözden Geçirilmiş ve Genişletilmiş 6.Bask1, Filiz Kitabevi, İstanbul 1988, s.664-668.

72 TEKINAY/AKMAN/BURCUOĞLU/ALTOP, s.668-669.

73 ARTUK, M. Emin/GÖKCEN, Ahmet/ALŞAHIN, M. Emin/ÇAKIR, Kerim: Ceza Hukuku Genel Hükümler, 12.Bask1, Adalet Yayınevi, Ankara 2018, s.10 vd; KOCA, Mahmut/ÜZÜLMEZ, İlhan: Türk Ceza Hukuku (Genel Hükümler), 12.Baskı, Seçkin Yayını, Ankara 2019, s.51.
} 
Cezaların tayininde kusurun veya manevi unsurun derecelendirilmesi adaletin bir gereğidir. Kusur ile ceza arasında veya manevi unsur ile ceza arasında bir orantının olması gerekir ${ }^{74}$. Suç sayılan fiilleri gerçekleştirmede esas olan kişinin kasten hareket etmesidir. Ancak kanunlar bazı suçların taksirle de işlenebileceğini öngörürler (örneğin TCK m. 22/1). Ancak gerek kast ve gerekse taksirin dereceleri vardır. 1926 tarih ve 765 sayılı Ceza Kanunu kusurun dereceleri olarak sadece kast ve taksirden söz etmekteydi ( 765 sayılı TCK m. 45). 2003 yılında 765 sayılı Kanunun 45. maddesine ek bir fikra eklenerek bilinçli taksir getirildi (m. 45/3). 2004 tarih ve 5237 sayılı Türk Ceza Kanunu manevi unsurun görünümleri olarak kast (TCK m. 21/1), dolaylı kast (TCK m. 21/1), taksir (TCK m. 22/2), ve bilinçli taksir (TCK m. 22/3), şeklinde bir ayrımı kabul etmiştir. Bu ayrım, ceza adaleti açısından daha adil ve hassas bir denge kurmuştur. Objektif sorumluluk anlayışından kusurlu sorumluluk anlayışına geçilmesi ceza adaleti bakımından nasıl önemli bir adım ise, kast ve taksir biçimindeki ikili bir ayrımdan, kast, dolaylı kast, taksir ve bilinçli taksir olarak dörtlü bir ayrıma geçilmesi de adil bir ceza sistemi açısından elzem bir gelişmedir. Bu ayrımla ceza adaleti daha hassas hale getirilmiştir.

Kusur ile ceza arasında mutlak bir oran söz konusu değildir. Oranlar genelde belirli bir ülkenin ceza politikasıyla ilgilidir. Bir ülkede bazı suçların taksirle işlenmesi çok fazla yaygın ise, bu suçların taksirle işlenmesinde diğer suçlara nazaran daha fazla ceza tayin edilebilir. Örneğin trafik kazaları dolayısıyla meydana gelen ölümleri azaltmak için trafikte taksirle ölüme sebebiyet vermenin cezası ağırlaştırılabilir. Ancak oranlar yine de sağduyu veya ortak vicdanın benimseyemeyeceği sınırları aşmamalıdır. Bu sınırın nasıl çizileceği meselesinde, hukukla yönetilen ülkelerin ortalaması bize yol gösterebilir. Sıkça işlenen bazı taksirli suçları önlemek amacıyla kusur ile ceza arasındaki oran bakımından bu ortalamalardan uzaklaşılabilir. Kusur ile cezalar arasındaki genel ortalamalardan, sağduyu ve ortak vicdanın kabul edemeyeceği aşırı sapmalar, adalet idealiyle uyuşmaz.

\section{e. Yetki ve Sorumluluk Arasındaki Oran}

Kamusal yetki kullanan kişilerin sorumlulukları, kullandıkları yetkinin kapsam ve derecesine göre belirlenmelidir ${ }^{75}$. Bu ilke, bir yönüyle yasa koyucuyu, bir başka yönüyle de mahkemeleri ilgilendiren boyutlara sahiptir. Yasa koyucu, kamu görevlilerin sorumluluklarını tayin ederken bu esası ölçü alması gerekir. Kamu görevlileri bakımından, "ne kadar yetki, o kadar sorumluluk" esası geçerli olmalıdır. Mahkemeler de, yasaların sustuğu yerde, sorumluları ve sorumluların derecesini belirlerken yine bu esasa göre hareket etmeliler. Tabii ki, idare, yetkisini aşıp kişilere idari işlem veya eylemle zarar verirse, zarara uğrayanlara karşı sorumludur. Bu sorumluluğu dolayısıyla ödediği zararlar bakımından kişisel kusuru olana rücu hakkı vardır. Burada idare hukukunun bu çetrefilli konularını tartışacak değiliz. Amacımız soyut planda, yetki ve sorumluluk arasındaki ilişkiyi temel adalet ilkeleri açısından ortaya koymaktır.

Yukarıda ifade ettiğimiz gibi, temel adalet ilkeleri açısından, yetki-sorumluluk ilişkisi, bir taraftan yasa yapım faaliyetini, diğer taraftan yargısal faaliyeti ilgilendirir. Yasal düzenleme seviyesinde, sorumluluk verilen yetkilerle orantılı olmalıdır. Yetkilerle orantısız olarak sorumluluk yüklemek eşyanın tabiatına aykırıdır. Nitekim Kur'an-1 Kerimde, Bakara Suresinin 286. ayetinde "Allah bir kimseyi ancak gücünün yettiği şeyle yükümlü kılar ${ }^{76 " ~ b u y r u l a r a k ~ b u ~ h a k i k a t ~ d i l e ~ g e t i r i l m i s ̧ t i r . ~}$ İlahi doğal hukuk bakımından geçerli olan bu ilke, aynı zamanda seküler doğal hukuk teorisinde de dile getirilir. Bir prosedürel doğal hukuk teorisi geliştirmeye çalışan Fuller, hukukun, insanlardan güçlerinin yetmediği şeyleri talep etmemesini bir doğal hukuk ilkesi biçiminde hukukun içsel ahlakı olarak sunmuştur ${ }^{77}$. Dolayısıyla hukukun genel ilkesi olarak sayacağımız bu esas, kamu hukuku veya idare hukuku bakımından, "sorumluluğun derecesi, yetkinin kapsamıyla orantılı olmalıdır" biçiminde tezahür eder. Bu da, vaz geçemeyeceğimiz adaletin asgari içeriğini oluşturur.

\section{f. Külfetler ve Nimetler Arasındaki Oran}

Külfetlerle nimetler arasındaki oran, hukukun en eski kaidelerindendir. Nitekim Mecelle madde 88'de de, "Külfet ni'mete, ni'met külfete göredir" ${ }^{78 "}$ șeklinde genel bir kaide bulunmaktadır. Külfetnimet orantıs1, nimetlerden yararlanmanın külfetlere bağlı olduğu durumlarda işleyen bir ilkedir. $\mathrm{Bu}$ bakımdan kamu hukuku ilişkilerinde bu ilkenin uygulanması yaygındır. İnsanlar, toplu halde yaşamanın getirdiği bir takım yükümlülükleri yerine getirme borcu altında oldukları gibi birlikte

\footnotetext{
${ }^{74}$ KOCA/ÜZÜLMEZ, s.51.

75 Bkz. ÇAĞLAYAN, Ramazan: İdari Yargılama Hukuku, Güncellenmiş 9.Baskı, Seçkin Yayıncılık, Ankara, s.623.

${ }^{76}$ Kur'an-1 Kerim, Bakara Suresi, 2/286, Diyanet İşleri Başkanlığı Meali, https://kuran.diyanet.gov.tr/mushaf/kuranmeal-2/bakara-suresi-2/ayet-286/diyanet-isleri-baskanligi-meali-1 (ErişimTarihi:19.03.2020).

${ }^{77}$ Bkz. FULLER, s.70 vd.

${ }^{78}$ Bkz. BERKİ, Ali Himmet: Açıklamalı Mecelle (Mecelle-i Ahkami Adliyye), 3.Baskı, Hikmet Yayınları, 1982 İstanbul s.27.
} 
yaşamın sağladığı imkânlardan da yararlanmaları söz konusu olur. Birlikte yaşamın getirdiği imkân ve nimetler, kural olarak katlanılan külfetlerle orantılı olmalıdır. Ancak engelli olma durumu gibi belirli külfet ve yükümlülükleri yerine getiremeyen kişiler bakımından, nimet külfet dengesi aranmadan söz konusu kişilerin nimetlerden faydalanması ahlakın bir gereğidir.

Dolayısıyla normal koşullarda nimet-külfet dengesi, özellikle kamu hukukunda birey ve toplum arasındaki yükümlülük ilişkisinin belirlenmesi bakımından önem arz etmektedir. Yargıtay bir kararında, daha fazla prim ödeyenin daha fazla sosyal yardımdan yaralanması gerektiğine ilişkin düşüncenin temeli olarak nimet-külfet dengesini göstermiş ve bu ilkenin sosyal güvenlik hukukunun temel esaslarından olduğunu belirtmiştii ${ }^{79}$.

\section{Hiç Kimsenin Kendi Haksızlığına Dayanarak Bir Hak Elde Edememesi}

Bir toplumsal ilişkiler ağında kusurlu hareket ederek bir haksızlık oluşturan kişi, bu kusurunun yarattığı yeni durumdan bir menfaat veya hak elde edememelidir. Bazen kusurlu haksız davranış cezai sorumluluğa yol açarken, diğer taraftan yasaların yetersizliğinden (boşluk veya belirsizliğinden) dolay1 haksız davranışı yapan kişi lehine görünüşte bir menfaat veya hak doğurabilecek bir izlenim ortaya çıarabilir. Adalet ve hakkaniyet ilkelerine bağlı kalınarak, yasaların boşluk veya belirsizliği kusurlu haksız davranışı yapan kişi lehine yorumlanmamalıdır. Amerika Birleşik Devletlerinde 1889 tarihinde Riggs v. Palmers davasında, New York Temyiz Mahkemesi, vasiyetnameyi değiştireceği endişesiyle büyükbabasını öldüren mirasçıya, yasaların her hangi bir yasaklama (mirastan mahrumiyet gibi) içermemesine karşın, "hiç kimse kendi haksızlığından bir menfaat elde edemez" ilkesine başvurarak vasiyetname gereği olan mirası vermeyi reddetmiştir ${ }^{80}$. Mahkeme'nin bu davadaki dikkat çeken akıl yürütmesi şu şekildedir:

“......ütün sözleşmeler gibi yasalar da uygulanmaları ve sonuçları bakımından common law'un genel ve temel ilkelerine göre denetlenebilir. Hiç kimseye kendi hilesinden yararlanmasina, kendi hatasindan avantaj elde etmesine, kendi haksızlı̆̆ına dayanarak bir talepte bulunmasına veya kendi suçuna dayanarak bir mülkiyet iktisap etmesine izin verilmemelidir. Kamu politikası tarafindan dikte edilen bu ilkelerin temelleri, bütün uygar ülkelerde uygulanan evrensel hukukta bulunmakta ve hiçbir yerde pozitif yasalar tarafindan çiğnenmemektedir ${ }^{81 "}$.

$\mathrm{Bu}$ meşhur karardan da görüldüğü gibi, her hangi bir suç, hile veya haksızlığın hukuken bir avantaja dönüşemeyeceği, bir evrensel hukuk ilkesi olarak Mahkeme tarafından saptanmıştır. Kişinin yaptığı bir haksızlıktan yaralanmasına firsat verilmesi, insanlığın vicdan ve sağduyusunu yaralayan bir durumdur.

\section{SONUÇ}

Hukuki pozitivistler, adalet değerinin hukuk kavramında yer almasına itiraz etseler de, pozitif hukukun, kabul edilemeyecek ve katlanılamayacak derecede adaletsizlik ve haksızlık unsurlarıyla kirlenmesinin önüne geçebilmek için üzerinde kolayca uzlaşılabilen veya kolay kolay reddedilemeyen asgari bir adalet kavramlaştırmasına ihtiyaç olduğu aşikârdır. $\mathrm{Bu}$ çalışmada asgari adalet kavramlaştırması, genel olarak bazı pozitivistlerin ahlaki rölativizme sığınarak hukuku, adaletten yoksun bırakılmış bir güç mücadelesi olarak algılamalarına bir cevap olarak tasarlandı.

Adalet kavramının bir bölümünün tartışmalı ve belirsiz olduğu reddedilemeyen bir gerçektir. Ancak adalet gibi hukuki değerlerin anlamlarının fiziki olgulara ilişkin ifadeler gibi sabitlenememesi, bu değerlerin önemlerini zayıflatmaz. Değerler, tamamen herkesin kabul edebileceği şekilde belirli kalıplara sokulamaz. Ahlaki değerler her çağın gereklerine yanıt verebilecek esnekliklere sahiptirler. $\mathrm{Bu}$ durum, bizim tamamen rölativizme saplanacă̆ımız anlamına gelmemelidir. Değerlerin belirsizlik alanları olduğu gibi belirlilik alanları da vardır. Adalet değeri de bir ahlaki değer olarak tartış1labilir esnek bir alana sahip olduğu gibi, bir de üzerinde kolayca uzlaşılabilen bir çekirdek alanı vardır. Bu çekirdek alanı oluşturan ilkelerin, asgari bir adalet kavramını oluşturabilecek açıklıkta oldukları

\footnotetext{
${ }^{79}$ Yargitay 10. Hukuk Dairesi, Esas Numarası:2009/11623, Karar Numaras1:2011/9839 Karar Tarihi:30.06.2011, Legal Bank, https://legalbank.net/belge/y-10-hd-e-2009-11623-k-2011-9839-t-30-06-2011-nimet-kulfet-dengesiilkesi/909549 (Erişim Tarihi:01.06.2020); ayrıca bkz. Yargitay Hukuk Genel Kurulu, E.2015/423, K.2017/1256, https://www.kararara.com/forum/viewtopic.php?t=404939 (ErişimTarihi:01.06.2020); İş kazalarında da sorumluluğun belirlenmesi açısından Yargıtay bu ilkeye başvurmaktadır. Yargıtay 21. Hukuk Dairesi, E.2016/115, K.2017/2948, Tarih: 10.04.2017. http://www.kazanci.com.tr/gunluk/21hd-2016-115.htm (ErișimTarihi:01.06.2020).

${ }^{80}$ Court of Appeals of New York 115 NY 506, 1889 http://www.courts.state.ny.us/reporter/archives/riggs_palmer.htm (ErişimTarihi: 18.02.2020); bkz. TÜRKBAĞ, Ahmet Ulvi: "Hart-Dworkin Tartışmasının Ana Hatları", in Ökçesiz, Hayrettin (ed), Hukuk Felsefesi ve Sosyolojisi Arkivi (HFSA), 16.Kitap, İstanbul Barosu Yayını, İstanbul 2007, s.327328; METIN, s.65 vd.

${ }^{81}$ Court of Appeals of New York 115 NY 506, 1889, http://www.courts.state.ny.us/reporter/archives/riggs_palmer.htm (ErişimTarihi:18.02.2020); bkz. TÜRKBAĞ, s.327.
} 
kolayca reddedilemeyen bir olgudur. Bu ilkelerin kaç tane olduğuna ilişkin bir sayı vermek doğru görünmüyor. Bu ilkelerin sayısı ne kadar sınırlı tutulursa, üzerlerinde o kadar kolay ittifak edilebilir. Biz de çalışma içerisinde kendi tercihimiz olarak bazı ilkeleri sayarak ana hatlarıyla önemli noktalarına temas ettik. Ancak daha önce belirttiğimiz gibi bu ilkeler, azaltılabilir veya artırılabilir.

Asgari adalet kavramında yer alan ilkelerin oluşturduğu alanın bazı özellikleri vardır. Birincisi, asgari adalet kavram alanı, siyasete duyarsızdır. Siyasi görüş ve tercihlerden etkilenmezler veya az etkilenirler. Daha doğru bir ifadeyle siyasi tercihlerden etkilenmeleri sınırlıdır. Asgari adalet kavramı alanı ne kadar dar tutulursa, siyasetten o kadar az etkilenir. Kavramı biraz genişletirsek siyasete duyarlılık başlamış olur. İkincisi, asgari adalet kavramını oluşturan ilkelerin ahlaki (moral) karakteri yüksektir. Yani bu ilkeler ahlaka duyarlıdır. Ahlaki değerlendirmelere ilişkin pratik akıl yürütmeler, bu alanın içeriği üzerinde etkili hassasiyetler oluştururlar. Asgari adalet kavramını daha geniş tutarsak, bu kavram alanının ahlaki olma niteliği zayıflamaya başlar. Üçüncüsü, asgari adalet kavram alanı evrenselleştirilebilir bir karaktere sahiptir. Yani asgari adalet kavramını oluşturan ilkelerin evrensellik karakteri yüksektir. Ancak yine bu ilkelerin sayısını artırıp söz konusu kavramı genişletirsek, evrensellik vasfından uzaklaşmaya başlamış oluruz.

Pozitif hukukun aşamayacağı bazı sınırlar oluşturabilmek için, asgari adalet kavramlaştırmasıyla ilgili düşünsel faaliyetlerin çoğalması gerekir. Üzerinde kolayca uzlaşılabilen bir ilkeler demeti oluşturma ve bunları ayrıntılı olarak tartışmanın, adalet kavramının belirlilik alanına katkı sağlayarak pozitif hukukun asgari ahlakiliği konusunda bir hassasiyet oluşturacağına inanıyoruz. Asgari adalet kavramını oluşturan ilke ve esaslarla çelişmeyen bir pozitif hukuk anlayışının, gerek insan hakları ve gerekse insan onurunun korunmasındaki önemi inkâr edilemez 
KAYNAKÇA

AKTAŞ, Sururi: Hayek'in Hukuk ve Adalet Teorisi, 2.Bask1, Liberte Yayın1, Ankara 2018.

AKTAŞ, Sururi: Prosedürel Doğal Hukuk: Fuller'in Hukuk Kavramı, 1.Baskı, XII Levha Yayını, İstanbul 2011. ARISTOTELES: Nikomakhos'a Etik, (Çev. Saffet Babür), Hacettepe Üniversitesi Yayınları, Ankara 1988.

ARTUK, M. Emin/GÖKCEN, Ahmet /ALŞAHIN, M. Emin / ÇAKIR, Kerim: Ceza Hukuku Genel Hükümler, 12.Bask1, Adalet Yayınevi, Ankara 2018.

BALMER, Thomas A.: "Some Thoughts on Proportionality", Oregon Law Review, 87(3), 2008, s.783-817.

BAYLES, Michael D.: Hart's Legal Philosophy, , Kluwer Academic Publishers, Netherlands 1992.

BECCARIA, Cesare: Suçlar ve Cezalar Hakkında (İtalyanca Aslından Çeviren: Sami Selçuk), 8. Baskı, İmge Yayınevi, Ankara 2019.

BENTHAM, Jeremy: The Theory of Legislation, (Ed. C. K. Ogden), Routledge Kegan Paul, London 1931.

BERKİ, Ali Himmet: Açıklamalı Mecelle (Mecelle-i Ahkami Adliyye), 3.Baskı, Hikmet Yayınları, İstanbul 1982.

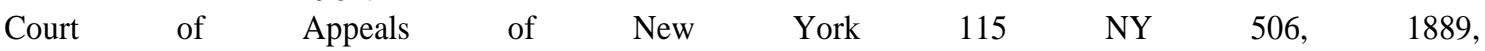
http://www.courts.state.ny.us/reporter/archives/riggs_palmer.htm (Erişim Tarihi:18.02.2020).

CULLISON, Allan D.: "Morality And The Foundations of Legal Positivism", Valparaiso University Law Review, 20(1),1985, s.61-70.

CURZON, L. B: Jurisprudence, 2nd Edition, Cavendish Publishing, London-Sydney 1995.

ÇAĞLAYAN, Ramazan: İdari Yargılama Hukuku, Güncellenmiş 9. Baskı, Seçkin Yayıncılık, Ankara.

ÇEÇEN, Anıl: Adalet Kavramı, 2.Basım, Gündoğan Yayınları, Ankara 1993.

DEFLEM, Mathieu: Sociology of Law, (Vision of Scholarly Tradition), Cambridge University Press, 2008.

DENIER, Yevonne: Efficiency, Justice and Care, Springer, Dordrecht, The Netherlands 2007.

DRURY, S. B.: "H.L.A. Hart's Minimum Content Theory of Natural Law”, Political Theory, Sage Publications, 9(4), 1981, s.533-546.

DWORKIN, Ronald: Hakları Ciddiye Almak, (Çev. Ahmet Ulvi Türkbağ) 1.Baskı, Dost Kitabevi, Ankara 2007.

DWORKIN, Ronald: Law’s Empire (Law's Empire), Harvard University Press, 1986.

FLETCHER, George P.: "Punishment and Responsibility", in Patterson, Dennis, (Ed.), A Companion to Philosophy of Law and Legal Theory, Second Edition, Wiley-Blacwell, 2010, s.504-512.

FULLER, Lon L.: The Morality of Law, Revised Edition, Yale University Press, New Haven and London 1969. GORDON, David: "Justice and Redistributive Taxation: James Buchanan versus Ludwig von Mises", The Review of Austrian Economics, 8(1),1994, s.117-131.

GÖZLER, Kemal: Hukuka Giriş, 15.Bask1, Ekin Yayını, Bursa 2018.

GÜRLER, Sercan: Ahlak ve Adalet: Çağdaş Ahlak Felsefesi ve Adalet Sorunu, 1.Baskı, Legal Yayıncılık, İstanbul 2007.

HALL, Stephen: "The Persistent Spectre: Natural Law, International Order and the Limits of Legal Positivism", Europen Journal of International Law, (EJIL), 2(2), 2001, s.269-307.

HART, H.L.A.: The Concept of Law, Second Edition, (With a Postcript Ed. by Penelope A. Bulloch and Joseph Raz) Clarendon Press-Oxford, 1994.

HAYEK, F. A.: The Constitution of Liberty, Routledge, London 1990.

HAYEK, Friedrich August von: Kanun, Yasama Faaliyeti ve Özgürlük Cilt.II (Sosyal Adalet Serabı) Çev. Mustafa Erdoğan, 1. Baskı, Türkiye İş Bankası Kültür Yayınları, 1995.

HENBERG, M.C.: "Nozick and Rawls on Historical Versus End-State Distribution", The Southwestern Journal of Philosophy, 8(2), 1977, s.77-84.

HIRSCH, Andrew von: "Proportionality in the Philosophy of Punishment", Crime and Justice, The University of Chicago Press, 16, 1992, s.55-98.

IŞIKTAÇ, Yasemin: Hukuk Felsefesi, 1.Baskı, Filiz Kitabevi, İstanbul 2004.

KALBERG, Stefan: "Max Weber's Types of Rationality: Cornerstones for the Analysis of Rationalization Processes in History" The American Journal of Sociology, 85(5), 1980, pp.1145-1179.

KELSEN, Hans: General Theory of Law and State, (General Theory), (Translated by Andres Wedberg), Third Printing, Harvard University Press, Cambridge, Massachussets 1949.

KELSEN, Hans: "The Pure Theory of Law and Analytical Jurisprudence", Harvard Law Review, 55(1), 1941, s.44-70.

KELSEN, Hans: What is Justice: Justice Law and Politics in the Mirros of Science, Collected Essays by Hans Kelsen, University of California Press, New Jersey, 2000.

KNOLL, Manuel: "The Meaning of Distributive Justice for Aristotle's Theory of Constitutions", П Н $\Gamma$ H / F O N S, I, 2016, s.57-97.

KOCA, Mahmut/ÜZÜLMEZ, İlhan: Türk Ceza Hukuku (Genel Hükümler), 12. Baskı, Seçkin Yayını, Ankara 2019.

KÖKÜSARI, İsmail: Anayasa Hukukunda Hukuki Güvenlik İlkesi, Birinci Baskı, Adalet Yayınevi, Ankara 2015. 


\begin{tabular}{lllllll}
\hline KUR'AN-I KERIM: & Bakara Suresi, 2/177, Diyanet İşleri & Başkanlı̆̆ & Meali,
\end{tabular}
https://kuran.diyanet.gov.tr/mushaf/kuran-tefsir-1/bakara-suresi-2/ayet-177/diyanetisleri-baskanligi-meali-1 (Erişim Tarihi:08.03.2020); Bakara Suresi, 2/286, Diyanet İşleri Başkanlı̆̆ı Meali, https://kuran.diyanet.gov.tr/mushaf/kuran-meal-2/bakara-suresi-2/ayet286/diyanet-isleri-baskanligi-meali-1 (Erişim Tarihi:19.03.2020); Maide Suresi, 5/1 Diyanet İşleri Başkanlığı Meali, https://kuran.diyanet.gov.tr/mushaf/kuran-tefsir-1/maidesuresi-5/ayet-1/diyanet-isleri-baskanligi-meali-1 (Erişim Tarihi:08.03.2020); Mutaffifin Suresi, 83/1-3, Diyanet İşleri Başkanlığı Meali, https://kuran.diyanet.gov.tr/mushaf/kuranmeal-2/mutaffifin-suresi-83/ayet-1/diyanet-isleri-baskanligi-meali-1

(Erişim Tarihi:08.03.2020).

LOCKE, John: Second Treatise of Government, Enhanced Media, Los Angeles 2016.

MCKENNA, Michael: "Compatibilism”, https://plato.stanford.edu/entries/compatibilism/ (Erişim Tarihi:05.02.2020).

METIN, Sevtap: "Ronald Dworkin'in Hukuk Teorisinde Yorum Yaklaşımı”, İstanbul Üniversitesi Hukuk Fakültesi Mecmuas1, LXI(1-2), 2003, s.35-83.

MILLER, David: Social Justice, Clarendon Press, Oxford 1976.

NARVESON, Jan: "Property Rights: Original Acquisition and Lockean Provisos", Public Affairs Quarterly, 13(3), 1999, s.205-227.

NOZICK, Robert: Anarchy, State and Utopia, Oxford 1974.

PLATO: The Republic, (Ed. by G. R. F. Ferrari; Translated: Tom Griffith), Sixth Printing, Cambridge University Press, Cambridge 2003.

RAWLS, John: A Theory of Justice, Revised Edition, Sixth Printing, Harvard University Press, Cambridge, Massachussets 2003.

REES, J.C.: "Hayek on Liberty", Philosophy, 38(146), 1963, s.346-360.

SCHIAVELLO, Aldo: “On 'Coherence' and 'Law': An Analysis of Different Models”, Ratio Juris, 14(2), 2001, s.233-243.

SCHMIDTZ, David: Adaletin Unsurları (Çev. Hayrettin Özler) 1.Baskı, Liberte Yayınları, Ankara 2010.

SEN, Amartya: The Idea of Justice, The Belknap Press of Harvard University Press, Cambridge, Massachussets 2011.

SUMMERS, Robert S.: "Professor Fuller on Morality of Law", Journal of Legal Education, 18(1), 1965, s.1-27. ŞAHIN CEYLAN, Şule: H.L.A Hart'ın Hukuk Kavramı, 1.Baskı, XII Levha Yayını, İstanbul 2014.

TEKINAY, S. Sulhi/AKMAN, Sermet/BURCUOĞLU, Haluk/ALTOP, Atilla: Borçlar Hukuku Genel Hükümler, Gözden Geçirilmiş ve Genişletilmiş 6.Baskı, Filiz Kitabevi, İstanbul 1988.

TURHAN, Mehmet: “Anayasanın Yorumlanmasında Felsefi Yaklaşım: Ronald Dworkin'e Göre Anayasanın Ahlaksal Okunuşu”, in Ökçesiz, Hayrettin/Uygur, Gülriz/Üye, Saim (ed), Hukuk Felsefesi ve Sosyolojisi Arkivi (HFSA) 26.Kitap, İstanbul Barosu Yayınları, İstanbul 2014, s.443480.

TÜRKBAĞ, Ahmet Ulvi: "Hart-Dworkin Tartışmasının Ana Hatları", in Ökçesiz, Hayrettin (ed), Hukuk Felsefesi ve Sosyolojisi Arkivi (HFSA), 16.Kitap, İstanbul Barosu Yayın1, İstanbul 2007, s.322-329.

USLU, Cennet: Doğal Hukuk ve Doğal Haklar, Liberte Yayını, Ankara 2009.

UYGUR, Gülriz: "Adalet ve Hukuk Devleti”, Ankara Üniversitesi Hukuk Fakültesi Dergisi, 53(3), 2004, s.2938.

WEBER, Max: Hukuk Sosyolojisi, (Çev. Latif Boyacı), 1.Baskı, Yarın Yayınları, İstanbul 2019.

WELLMAN, Carl: The Moral Dimension of Human Rights, Oxford University Press 2011.

WOLTERSTORFF, Nicholas: Justice: Rights and Wrongs, Princeton University Press 2008.

Yargitay Hukuk Genel Kurulu, E.2015/423, K.2017/1256, https://www.kararara.com/forum/viewtopic.php?t=404939 (Erişim Tarihi:01.06.2020).

Yargitay 10. Hukuk Dairesi, Esas Numarasi: 2009/11623, Karar Numarası: 2011/9839 Karar Tarihi: 30.06.2011, Legal Bank, https://legalbank.net/belge/y-10-hd-e-2009-11623-k-2011-9839-t-30-062011-nimet-kulfet-dengesi-ilkesi/909549 (Erişim Tarihi:01.06.2020).

Yargitay 21. Hukuk Dairesi, E.2016/115, K.2017/2948, Tarih:10.04.2017. http://www.kazanci.com.tr/gunluk/21hd-2016-115.htm (Erişim Tarihi:01.06.2020). 